\title{
Acı Așk Filminin “Erkeklik Krizi” Bağlamında İncelenmesi
}

\author{
Rifat BECERIKLі' \\ Sefer KALAMAN ${ }^{2}$
}

Öz

Toplumsal yapı temel olarak insanların beraber yaşadığı bir alandır. Aynı şekilde toplumda kadınlık ve erkeklik temsillerinin sürekli var olduğu bir gerçektir. Kadın ve erkek arasındaki ilişkiler ise belirli kültürel özellikler ve sosyalizasyon süreçleri sonucunda öğrenilir. Dünyanın değişik yerlerinde birbirinden tamamen farklı kadınlık ve erkeklik temsilleri bulunmaktadır. Diğer yandan bu temsiller durağan ve sabit değil zamana göre değişebilen yapıya sahiptir. Türkiye'de zaman içinde toplumsal değişme ile birlikte kadın ve erkeğin kültürel olarak tanımlanan bazı özellikleri farklılaşmaya başlar.

Genelde medya özelde ise sinema filmleri kadın ve erkeklik temsillerinin rol model olarak yeniden üretildiği, dolaşıma sokulduğu bir alan işlevi görmektedir. Feminist araştırmalar kadınlık temsilleri üzerine çalışmalar olarak görülse de son yıllarda erkeklik temsilleri üzerine yapılan incelemelerde de bir artış bulunmaktadır. Erkeklik araştırmaları geleneksel ataerkilliğin son yıllarda aşındığı, kadınların iş yaşamında, kamusal alanda daha etkili olduğu fikri üzerinde durmaktadır. Bu açıdan geleneksel erkek iktidarının toplumsal alanda bir güç kaybına uğradığı savı öne çıkmaktadır. Genel olarak eril otoritenin baskınlığının azalması "erkeklik krizi" olarak adlandırımaktadır.

Çalışma kapsamında senaristliğini Onur Ünlü'nün, yönetmenliğini Taner Elhan'ın yaptığı Acı Aşk (2009) filmi örneklem olarak seçilmiştir. Araştırmada nitel film analizi yöntemi ve betimleme tekniği kullanılmıştır. Acı Aşk filmi, Türk sinema tarihinde öne çıkan Yeşilçam dönemindeki erkeklik temsilleri ile karşılıklı analiz edilmiştir. Ayrıca filmdeki erkeklik ve erkeklik krizi olguları iktidar, cinsellik, kadın-erkek ilişkileri, ekonomi bağlamında incelenmiştir. Sonuç olarak Acı Aşk filminin genel olarak Yeşilçam filmlerinden farklı bir erkeklik imajı tanımladığı ortaya çıkmaktadır. Filmde modern ve eğitimli olsa bile kadınlar ile ilişkisini iktidar ve otorite temelinde kuran erkek karakterin yaşadığı eril krizler betimlenmektedir.

Anahtar Kelimeler: Türk Sineması, Erkeklik, Erkeklik Krizi.

Atıf: Becerikli, Rifat ve Kalaman, Sefer (2019) Acı Așk Filminin “Erkeklik Krizi” Bağlamında İncelenmesi. Akdeniz Üniversitesi Iletișim Fakültesi Dergisi (AKiL) Haziran (31) s. 512-536

1 Dr. Öğr. Üyesi Rifat BECERiKLi, Yozgat Bozok Üniversitesi İletişim Fakültesi. rifat.becerikli@bozok.edu.tr ORCID ID: 0000-0001-6392-8330

2 Dr. Öğr. Üyesi Sefer Kalaman, Yozgat Bozok Üniversitesi İletişim Fakültesi. sefer.kalaman@bozok.edu.tr ORCID ID:0000-0002-2761-1229 


\title{
An Analysis Of Acı Așk In The Context Of “Crisis Of Masculinity”
}

\begin{abstract}
The social structure is constitutively a space where people live together. Accordingly, it is a fact that representations of femininity and masculinity constantly exist in society. These relations are the behaviors that are acquired in consequence of specific cultural aspects and socialization processes. There are totally different representations of femininity and masculinity in different parts of the world. On the other hand, these representations are not fixed and have a structure that can differ in the course of time. Some culturally described characteristics of men and women have began to change in Turkey with social changes.

Media and movies are spaces where the representations of femininity and masculinity are delivered and reproduced as role models. Although feminist studies are generally regarded as studies on women, there has been an increase in studies on masculinity in recent years. Masculinity studies emphasize that traditional patriarchal social structure are eroded in recent years and women become more effective in public space and professional life. In this respect, the argument, which the traditional male power has lost his power in the social sphere, becomes prominent. The decrease of male dominance is generally called "crisis of masculinity".
\end{abstract}

Acı Aşk (2009) directed by Taner Elhan and written by Onur Ünlü was chosen as a sample. Qualitative film analysis method and descriptive technique were used in the study. Acı Aşk was comparatively analyzed with the representations of masculinity in these two periods which were prominent in the history of Turkish cinema. In addition to that, the issues of masculinity and the crisis of masculinity in the film were examined in terms of power, sexuality, male-female relations, and economy. As a result, it appears that Acı Aşk has defined a different masculinity image than Yeşilçam films. In the film, masculine crises described in which the male character who establishes the relationship with women on the basis of power and authority

Keywords: Turkish Cinema, Masculinity, Crisis of Masculinity.

\section{Giriș}

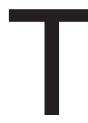
oplumsal yapı temel olarak insanların birlikte var oldukları bir alandır. Birçok ülkede farklı toplumsal katmanlar mevcuttur ve birçok toplumsal yapı kendine has toplumsal katmanlardan oluşur. Bu açıdan kadınların ve erkeklerin davranış, düşünüş ve yaşayış biçimleri toplumsal yapı ve bulundukları toplumsal sınıf ile yakından ilişkilidir. Kadın ve erkek arasında bazı biyolojik farklılıklar olmasına karşın çoğu farklıık tamamen kültürel ve sosyaldir (Dökmen, 2016:144). Kültürel yapı, yaşanılan toplumsal alan ve insan iç içedir. Bu bağlamda erkeklik ve kadınlık süreç sonucunda öğrenilmiştir (Paechter, 2007: 6). Bu süreçler de büyük oranda toplumsal alanda sosyalizasyon ile 
mümkündür. Medya metinleri bağlamında sinema filmleri de bu sosyalizasyonda temel yürütücü unsurlardan biridir. Günümüzde birçok insan medya metinlerinden zaman ve uzam fark etmeksizin etkilenmektedir. Medya metinlerinin önemli türlerinden biri de sinema filmleridir. Maddi kültür sinema tarafından yaratılan ve beslenen görüntülerden doğrudan etkilenir çünkü sinema bireylerin ya da grupların kolayca özdeşleşebileceği görüntüler sunar (Güçhan, 1992:67). Filmsel evrendeki bu özdeşleşme daha sonra toplumsal davranışlara yansır. Filmler genel itibari ile insanı konu edinen yapıtlardır. Türsel olarak ister komedi ister korku ya da gerilim filmleri olsun anlatılan hikâyeler/ olay örgüleri, resmedilen karakterler muhakkak insanla bağlantı içermektedir. İnsan da biyolojik ve toplumsal cinsiyet özelliklerine göre toplumda ve dolayısıyla sinemada var olur. Sinemanın en önemli niteliklerinden biri kadınlar ve erkekler üstünde rol modeli etkisi yapabilmesidir. Sinema, erkeklik ve kadınlık modellerinin ulusal düzeyde yaratılmasını ve dolaşıma sokulmasını sağlar (Mora, 2006:3). Bu bağlamda filmler hem bir rol modeldir hem de bu rol model toplumsal alanı etkileyerek insanların davranış kalıplarını belirleyebilmektedir. Sinema, kadınlar/dişilik ile erkekler/erillik, kısacası cinsel farklılıklar üzerine mitlerin üretildiği ve bunların temsil edildiği kültürel bir pratiktir (Smelik, 2008:1). Filmi tüketen izleyici hikâyedeki kadın ve erkek gibi olmaya özenir ya da en azından davranış, beden dili, kıyafet, konuşma gibi özellikleri kendine uyarlayabilir. Bununla birlikte seyirciler filmde özdeşleştiği karakterlerin yaşadığı duygu durumları ile de katharsis/arınma yaşayabilir. Medya metinleri ve sinema filmlerinde erkek temsiline, erkeklik özelliklerinin dışavurumuna da rastlanır. Erkek/erkeklikler sadece bireyler değil gruplar, kurumlar ve özellikle kitle iletişim araçları ile sahnelenir ve sürdürülür (Connell, 2000:217). Sinema toplumsal alandaki egemen erkeklik düşüncesinin yansımalarının/sorunlarının kendisini ifade edeceği bir alandır. Sosyal bilimler alanında erkeklik üzerine araştırmalar özellikle son yıllarda büyük artış göstermektedir. Erkeklik çalışmaları olarak adlandırılan bu incelemelerin temel olarak feminist kuramın ya da feminist eleştirinin bir devamı niteliğinde olduğu söylenebilir. Erkeklik çalışmalarının odaklandığı noktalardan biri de "erkeklik krizi" olarak adlandırılan eril iktidar krizidir.

\section{Erkeklik Kavramına Genel Bakıș}

Erkeklik kültürel anlam olarak farklı şekillerde tanımlanmaktadır. Bu bağlamda erkeklik en temelde bir iktidar konumudur (Sancar, 2016:16). Bu konumdan gelen güç ve istediklerini yaptırma erki ile erkekler genel olarak iktidarlarını devam ettirme amacındadır. Aynı şekilde erkeklik kendini kurduğu iktidar vasıtasıyla sürdürmektedir. Kültürel olarak erkeklik güç ve aktiflik, kadınlık ise pasiflikle ilişkilendirilir (Hooper, 2001 :44). Erkekler iktidarlarını çoğu zaman güç ile sürdürürler. Diğer yandan erkeklik kaslı vücut ve sertlik kavramlarıyla da tanımlanır (Mora, 2006:120). Bu tanımlama güçlü oldukları imajını pekiştirir. Erkekler sembolik gücünü ise temelde hiyerarşik ilişkiden kazanır (Segal, 1993:635). Kendisine hiyerarşide üst tarafta yer bulduğunu farz eden erkekler, karşılarında hiyerarşide altta olan kadınların olduğu düşüncesindedir. Buna karşın erkeklik kavramı herhangi bir kişi ya da grup tarafından yaratılmamıştır; temelde erkeklik bir ideolojidir (Reeser, 2010:20). Gerçekliği şüpheli bir takım düşünce ve 
idealler, erkeğin davranış kalıplarına sabit metinler şeklinde uyarlanır. Bu bağlamda erkekler doğmaz, yapılırlar; erkekliklerini toplumsal ve tarihi bağlamda inşa ederler (Kimmel ve Messner,2010:xvii). Her erkek belli bir toplumsallaşma sürecinden geçer. Erkek sosyalizasyonu, erkek kabul edilmek için toplumsal ve kültürel kodları, rolleri ve normları içselleştirme anlamına gelir (Bozok, 2011:71). Benzer yönleri bulunsa da farklı coğrafyalarda farklı erkeklik özellikleri görülebilir. Bu durum erkeklik ve kültür arasında doğrudan bir ilişki olduğunu düşündürmektedir. Erkeklik muazzam miktarda kültürel anlam taşıyan bir simgedir (Nayak ve Kehily, 2013:65). Bu kültürel unsurların temeline bakıldığında ise ataerkil düşünce ya da ideoloji ile karşılaşılır. Diğer bir deyişle erkeklik inşa edilerek nesiller boyu aktarılan ataerkil kültüre dayalıdır (Connell, 2005:10). Lotz'a göre ise ataerkil yapı, kültürün erkek egemenliğini güçlendiren davranış ve özellikleridir (2014:20). Ataerkil düşünce, iktidar kavramı ile de yakından ilgilidir. Ataerkil ideoloji ya da sistemin temelde erkek iktidarının devam etmesi amacında olduğu söylenebilir. Bu bağlamda erkekler ataerkil çıkardan, hegemonyadan ve kadınların boyun eğmesinden kazançlıdır (Kimmel ve Aronson, 2004:509). Ataerkil sistemde erkeklerin yapısal avantaj ve imtiyazları vardır (Pease, 2014:21). Bu avantaj ve imtiyazlar sosyal hayatta, kişisel ve iş yaşamı dahil birçok alanda erkeğin sözünün dinlenilmesi onun istediklerinin yapılmasını sağlar. Erkekler genelde ataerkillikten kar, fayda, prestij ve yönetme hakkı elde eder (Connell, 2000:209; 2005:82). Bu durum da ataerkil erkekliğin bir çıkar ortaklığı olduğunu akla getirmektedir. Erkekler bu çıkar ortaklığı için ataerkil sistemi savunmaktadır.

Erkeklik düşüncesinin bir diğer temel unsuru aile ile olan ilişkide gizlidir ve bu durum da ataerkil yapıyla ilişkilidir. Erkeklerin ailedeki otoritesi ve ailenin geçimini sağlaması "erkeklik" düşüncesinin temelidir (Hobson ve Morgan, 2004:5). Diğer yandan ailenin kendisi de erkeklik düşüncesinin oluşturulduğu ve devam ettirildiği bir alan işlevi görmektedir. Erkekliğin temeli aile ve akrabalık ilişkilerinde inşa edilir (Aboim, 2010:61). En yakın ilişki birimi olarak aile, erkekliğin anlamını üyeleri itibari ile belirlemektedir. Bunun yanında kadına ait roller de inşa edilmektedir. Ataerkil ideoloji temel olarak ailenin babası tarafından şekillendirilir. Ataerkil ilişkiler refahı kontrol eden erkekler tarafından devam ettirilir ya da yeniden üretilir (Hearn, 2004:253). Bu bağlamda özellikle geleneksel ataerkillikte en geniş iktidar alanı babaya aittir.

Erkeklik alanında son yıllarda öne çıkan bir kavram da hegemonik erkekliktir. Hegemonik erkeklikle (eril erkeklik) kastedilen; sosyal ilişkilerde anlamı belirleyen, sözü sabitleyen, baskınlığını her türlü tavır ve davranışıyla teyit ettiren bir özne olma halidir (Cengiz, Tol ve Küçükural, 2004:51). Aynı şekilde hegemonik erkekliğe daha fazla yaklaşan erkekler, ataerkil iktidardan daha fazla pay alırlar; erkekler hegemonik erkekliği öne sürerek, farklı stratejilerle ataerkilliğin yeniden inşasına katkıda bulunur (Bozok, 2011:46). Birçok açıdan ataerkillik ile hegemonik erkekliğin benzeştiği görülmektedir. Bütün erkekler ataerkillik içinde sosyalleşirler (Pease, 2014:21). Bu bağlamda ataerkil bakış açısı genel olarak tüm erkekler tarafından doğal, normal ve meşru olarak kabul edilir. Aynı şekilde hegemonik erkeklik, erkeklerin egemen durumunu ve kadınların boyun eğmesini garanti eden (veya güvence altına alan) ataerkillik meşruiyet sorununa bir çözüm yoludur (Kimmel ve Aranson, 2004:508). Hegemonik erkeklik bir 
anlamda ataerkil kültürün/erkekliğin sistematize edilmiş hali olmaktadır. Ataerkil temeli olan erkekler, hegemonik erkeklik ile yakın ilişkidedir (Connell, 2005:241). Bu açıdan hegemonik erkeklik ataerkil düşüncesinin devam ettirildiği bir ideolojik stratejiler dizgesidir.

\section{Erkeklik Krizi Kavramına Genel Bakıș}

Erkeklik krizi olarak adlandırılan olgu toplumsal dönüşüm dönemlerindeki özellikle de sosyal ve ekonomik değişimlerde ön plana çıkmaktadır. Erkeklik son yüzyılda sürekli “kriz” ile birlikte anılmıştır, 1930'larda Büyük Buhran, 1950'lerde fordizm ile birlikte işlerin basitleşmesi ve 1970'lerin sonu ve 1980'lerin başında sanayileşmenin doygunluk noktasına ulaşmasıyla işsizlik ve imalat yapan yerlerin kapanmasıyla birlikte erkekliğe dair krizler görülmüştür (Roberts, 2014:5). Bu açıdan erkeklik krizi günümüzde ortaya çıkan bir durum olmamakla birlikte tarihsel arka planı da bulunmaktadır. Ayrıca erkeklik krizi tekrarlayan bir fenomendir (Kimmel \& Aranson, 2004:534). Savaş, ekonomik olumsuzluklar, yeni teknolojiler vb. tarihsel süreçte birçok defa çeşitli şekillerde ortaya çıkmaktadır. Günümüzdeki erkeklik krizinin ise daha çok ekonomi ve iş yaşamı temelli olduğu vurgulanmaktadır. Son dönemdeki kadın-erkek ilişkisindeki sıkıntının kaynağı, erkeklerin artan işsizliği ve kadınların işgücü katıımındaki yüksekliğidir (Robinson ve Hockey, 2011:26). Bu bağlamda özellikle ekonomik kriz dönemleri ile erkeklik krizi arasında doğru orantı olduğu söylenebilir. Leonard, erkeklik krizi bağlamında Amerika Birleşik Devletleri'nde 2007 yılındaki mortgate/ ekonomik çöküşünün kadınları ve erkekleri derinden etkilediğini belirtir (2014:33). Aynı şekilde erkeklik krizinin algılanışı, işsizlik ile ayrılmaz bir biçimde ilişkilidir (Ingram ve Waller, 2014:36). Diğer bir ifade ile işini kaybeden erkek, kimliğini ve öz saygısını ağır bir tehdit altında hisseder (Goldberg, 2018:238). Ekonomik olarak güçlü olmak erkeğe psikolojik olarak özgüven getirmektedir. Goldberg, işsiz kalan bir erkeğin cinsel sağlık sorunları yaşadığını (iktidarsızlık vb.) da belirtir (2018:49). Bu bağlamda toplumsal alandaki güç ve otorite ile cinsellik arasında doğrudan bir ilişki kurmak da mümkündür. Diğer bir ifade ile erkek cinselliği ile iktidar arasında yakın ilişki vardır (Segal,1992:257). Erkeğin iktidarını ilk önce cinsel alanda ispat etmesi istenir (Selek,2014:22). Bu durum da cinsellik, erkeğin en temel özelliklerinden biri haline getirir.

Cinsellik ve ataerkillik bağlamında diğer bir unsur da heteroseksüelliktir. Erkeklik temel olarak ataerkil düşünce bağlamında heteroseksüellik ile ilişkilendirilir. Bu açıdan erkeklik krizinin bir diğer nedeni olarak feminist, gay, lezbiyen vb. hareketlerin de büyük etkisi bulunmaktadır (Frosh, Phoenix ve Pattman, 2002:51). Aynı şekilde farklı cinsel kimliklerin özellikle ataerkil, eril iktidara bir tehdit algısı oluşturduğu söylenebilir. Diğer yandan erkeklik krizi toplumsal alana değil bireysel erkeklik psikolojisine de bağlı bir durumdur. Erkek sadece çevresine ve topluma değil, kendine de erkekliğini ispat etmek zorundadır, genellikle bu ispat gerçekleşmediğinde erkeklik krizi meydana gelir (Selek, 2014:214). Erkeklik diğer erkeklere gösterilen davranışlar bütünüdür ve diğer erkekler tarafından yargılanır (Kimmel, 2008:51). Yargılamadan olumlu olarak geçemeyen erkek ise kendisini yetersiz hissetmeye başlayabilir. Bu bağlamda Bourdie'ye göre eril 
imtiyaz bir tuzaktır; erkeklerin her koşulda erkekliğini ispatlamaya zorlayacak ölçüde abesleşebilen, daimi bir gerilim ve çekişme alanıdır (2015: 68). Erkeklerin sürekli olarak kendilerini göstermek için aktif olması bir süre sonra psikolojik olarak onları rahatsız etmektedir.

Günümüzde erkeklerin ekonomik ve kültürel olarak yerlerinden edildikleri için krizde olduğu görüşü de bulunur (Nayak ve Kehily, 2013:51). Bu yerlerinden edilme erkeklere hakim konumlarını kaybetme duygusunu ve kadınlar ile bir mücadelede olduklarını hissettirmektedir. Kadının özgürleşmesi, kamusal alanda daha görünür olması vb. nedenler ile erkek, erkekliğini kabul ettirmek için daha çok mücadele etmek zorunda kalır (Erkılıç, 2011:232). Bu durum sosyal alanda erkeğin iktidarını kısıtlayan ya da otoritesini paylaşmak zorunda kaldığı bir yapı oluşturur. Aynı şekilde aile erkeklik olgusunun işlemesinde temel unsurlardır biridir. Erkeklik krizinin bir diğer boyutu geleneksel aile içindeki babalık kavramında ortaya çıkar. Babanın aileyi geçindirecek ekonomiden yoksun olması ya da çok çalışması nedeniyle ailesi ile duygusal bağ kuramama sorunları temelinde de bir kriz içinde olduğu söylenebilir (Hobson ve Morgan, 2004:6). Buna karşın Ging erkeklik krizini, ataerkillik krizine benzetmektedir (2013:105). Ataerkil düşüncenin giderek toplumsal alanda aşınması kadın ve eşcinsel haklarının ön plana çıkarılması ataerkil düşünceyi de zorlamaktadır. Bu değişimin erkeklerin daha önce kendilerine hak olarak verilmiş bazı ataerkil değerlerin yok olması şeklinde ilerlemesi de etkilidir. Öte yandan erkeklik krizinde çoğu erkek değişim arayışında nereye yöneleceğini bilememektedir (Hooks, 2018:151). Bir yandan yıllardan beri süregelen ataerkil düşünce aşınırken yerine koyacakları hakim bir ideoloji bulamamaları erkeklerin nasıl yol alacaklarını zorlaştırır.

\section{Türkiye'de Erkeklik ve Erkeklik Krizi}

Türkiye'de yıllardır süregelen ataerkil erkek iktidarının genel olarak günümüzde de devam ettiği görülmektedir. Araştırmalarda ülkemizde toplumsal cinsiyet hakkında "erkek ve kadın yaratııştan farklıdır; kadın doğum yapmalı evine bakmalıdır, erkek egemenliği evrenseldir” düşünceleri baskındır (Sancar, 2016:184-186). Benzer şekilde kadın-erkek eşitliği konusunda genelde erkeklerin hiyerarşik olarak üstte olduklarını inancı hakimdir (Boratav, Fişek ve Ziya, 2017:187). Ülkemizde erkekler için özellikle cinsel anlamda başarılı ve güçlü olmak önemli bir unsurdur. Türkiye'de cinsellik temelinde erkeklerin ilk gecede cinsel ilişkide başarılı olma korkusu bulunmaktadır (Selek, 2014:19). Ayrıca Türkiye'de genç erkeklerin "adam olmayı" cinsellikle ilişkilendirdikleri de görülmektedir (Boratav ve diğerleri, 2017:260). Diğer yandan cinsel performansa göre şekillenen erkekler arası hiyerarşi bulunmaktadır (Sancar, 2016:196). Toplumsal alanda erkekler cinsel performansları ile diğer erkekler arasında kendilerini üstte konumlandırmaktadır. Bu bağlamda cinsellik ve iktidar beraber anılmaktadır. Cinsel olarak güçlü olmak erkeğin temel değeri haline gelmektedir. Diğer yandan cinsel anlamda başarılı olmanın bir uzantısı da çocuk sahibi olmak/ olabilmek diğer bir anlatımla baba olmak/olabilmektir. Babalık "erkekliğini" ispatlayan erkeklerin konumudur (Selek, 2014:22). Bu açıdan baba olamamak da bir güçsüzlük ve iktidarsızlık ifadesi olabilmektedir. 
Türkiye'de ataerkil yapının çeşitli sebeplerle aşındığı eril iktidar krizinin görünür olmaya başladığı dikkat çekmektedir. Örneğin toplumsal yapının hızla modernleşmesi, kadınların eğitim seviyelerinin artması, erkek işsizliğinin yükselmesi eril krizin sebepleri olarak sıralanabilir. Türkiye'de erkeklerin ataerkil bağlamda kadınlardan bir takım rol beklentileri bulunmaktadır. Bu açıdan kadınların üstlendikleri temel rol, erkeklerin kendi güçlerini ve egemenliklerini görmeye alıştıkları "ayna" görevi görmektir (Onur ve Koyuncu, 2004:33). Diğer bir ifade ile ataerkillikte erkeğin güçlü olmasının temel dayanağı kadındır. Kadın üzerinde iktidarını kuramayan erkek için eril krizden söz edilebilir. Bu bağlamda son yıllarda ülkemizde kadınların toplumsal alanda, iş ve sosyal yaşamda daha çok görünür olduğu söylenebilir. Türkiye'de 2000'li yıllardan sonra, en azından yasal zeminde, kadın ailenin veya namusun sembolü değil birey olarak kabul edilmeye başlanmıştır (Selek, 2014:27). Son dönemde, yüzyıllardır egemen olan kadın ve erkek arası rol dağılımında kadın tarafında yaşanan hızı bağımsızlıkçı gelişmeler bulunmaktadır (Onur ve Koyuncu, 2004:36). Bu gelişmeler eril imtiyaz sahibi bazı erkekleri de rahatsız etmektedir. Bunun nedeni olarak Türkiye'de erkekliğin kamusal alanda iyi bir konumda olmak anlamına gelmesi gösterilebilir (Boratav ve diğerleri, 2017:264). Kadınların toplumsal alanda erkeklerden daha iyi mevkilere gelmeleri de bir eril iktidar kaybını beraberinde getirmektedir. Türkiye'de erkekliğin ekonomi ile olan ilişkisinin bir özelliği de iyi bir gelire sahip olmaktır. Bir erkeğin gerçek bir erkek olarak görünmesinin ilk ölçütü düzenli bir işi olmasıdır (Sancar, 2016:102). Aynı şekilde Yavuz, Türkiye'de erkeğin işinin olmasının ekonomik durumunun yerinde olmasının temel güç ve iktidar kaynağı olduğunu belirtmektedir (2014: 122-124). Kadınların iş yaşamında artan etkinliği erkekleri rahatsız etmektedir. Türkiye'de toplumsal yapıya göre, erkekler eve ekmek parası getirir, aile kurabilir, soylarının devamlılığını sağlayabilir; bu, günümüzde erkek egemenliğinin merkezini oluşturan aksi olduğunda ise erkeklik krizine yol açan temel unsurdur (Bozok, 2018:34). Ayrıca Türkiye'de geleneksel toplumsal düzendeki değişim ve modernleşme ailenin yapısını da dönüştürmektedir. Yaşıı erkek iktidarı yerine, kendi ailesini kurup geçimini sağlamak için gençler kapitalist piyasada emeğini satmaya başlar (Sancar, 2016:122). Diğer yandan piyasa ekonomisindeki ucuz iş gücü, yüksek çalışma saatleri özellikle erkeklerin iş yaşamındaki sorunlarını da beraberinde getirir. Bununla birlikte sanayi sonrası dönemde erkeklerde yükselen işsizlik, "erkekliğin yitimi" hissine yol açar (Sancar, 2016:102). Ekonomik olarak ailenin geçimini temin edememek düşüncesi erkeğin kendisinde bir özgüven kaybına neden olur. Türkiye'de genç erkeklerin geçim sıkıntısı, işsizlik ve gelecek kaygısı taşıdıkları ortaya çıkmaktadır (Boratav ve diğerleri, 2017:147-150). Bu sorunlar da üstesinden gelinemediğinde özellikle psikolojik olarak erkekleri olumsuz etkilemektedir. Diğer yandan Türkiye'de erkeklerin büyük çoğunluğunun eşlerinin çalışmasına sıcak bakmadıkları tespit edilmektedir (Boratav ve diğerleri, 2017:177). Bunun temel nedeni olarak eşlerinin çalışması ve ev ekonomisine katkıda bulunmasının erkek iktidarının zayıflamasına sebep olduğu düşüncesi gösterilebilir. Aynı şekilde bu durumun nedenini erkekler genel olarak şöyle açıklamaktadır: "karısı çalışan bir adam erkekliğin en önemli tanımlarından olan 'evin ekmeğini' kazanma durumunu eşiyle paylaşarak hem erkekliğini tehdit altında bıraktığını hisseder, hem de karısını özgürleştirerek onu kaybetme riski taşır" (Boratav ve diğerleri, 2017:272). 
Türkiye'de eril krizin bir diğer yansıması da ebeveyn-çocuk ilişkisinde görülür. Çocuklar aile içinde kendilerine rol modeli aldıkları ebeveynler tarafından yetiştirilmektedir. Türkiye'de baba ile çocuklar arasında "iletişim kopukluğu" temel bir sorundur (Boratav ve diğerleri, 2017:124). Bu bağlamda ülkemizdeki erkeklik krizine baba-oğul ilişkisi ekseninde de yaklaşmak gerekmektedir. Sancar'a göre: "egemen erkeklik değerlerinin Türkiye'de babalardan oğullara kolay geçmediği ve genç kuşak erkeklerin ciddi bir erkeklik değerleri krizi ile karşı karşıya olduğu açıktır" (2016:125-126). Türkiye'de baba-oğul arasında da eril bir krizin başladığı söylenebilir. Babalar, oğullarını anlamak ve desteklemek amacıyla değil, onlara sorumluluklarını öğretmek ve oğullarının toplumdan kabul görmelerini sağlayacak erkeklik davranışlarını benimsetmek için onlarla baskı-otorite ilişkisi kurmaktadır (Sancar, 2016:126). Bu baskı, otorite ise erkeklerin babalarından gittikçe uzaklaşmasına neden olmaktadır. Türkiye'de genç erkeklerin babalarıyla olan ilişkilerini hiyerarşi, saygı, korku, mesafe, kısıtlanma, dayak, ceza, disiplin gibi kavramlarla tanımladıkları görülmektedir (Boratav ve diğerleri, 2017:95-106). Bu olumsuz tanımlamalar da temel olarak olumsuz ilişkileri akla getirmektedir. Genel olarak Türkiye'de muktedir, güçlü erkek portresi toplumsal yapıdaki değişmelerle birlikte sorunlarla boğuşan, çıkmaza giren, ekonomik sorunlar içinde ve psikolojik olarak yıpranmış erkeğe doğru evrilir.

\section{Türk Sineması'nda Erkeklik Olgusu}

Türk sineması incelemelerinde tarihsel olarak birçok farklı dönemlendirme yapıldığı görülmektedir. Buna karşın belirgin olarak iki farklı dönemin Türk sinemasında hakimiyeti söz konusudur. Bunlardan biri Yeşilçam sineması olarak adlandırılan kabaca 1950-1970 yılları arasındaki dönem diğeri ise 2000'li yıllar sonrası Yeni Türk sinemasıdır. Bu dönemler erkeklik olgusu bakımından incelendiğinde filmlerde farklı temsil biçimleri tespit edilmektedir.

1950'li yılların sonundan itibaren Türk sineması hızlı bir gelişim gösterir. Bu gelişim Yeşilçam melodram filmlerinin ortaya çıkmasını sağlar. Yeşilçam popüler ve ticari bir sinema olması nedeniyle Hollywood ile benzerlikler göstermektedir. Hollywood filmleri genel olarak ataerkil bilinçaltı ile inşa edilmektedir (Kaplan, 1983:30). Bu açıdan erkeğin kadınlar üzerindeki dominantığı birçok filmde ana unsur olarak yer almaktadır. Aynı şekilde Hollywood filmleri kadını, erkek iktidarının pasif doğrulayıcıları olarak konumlandırmaktadır (Ryan ve Kellner, 2010: 219). Bu durum genel olarak Yeşilçam filmleri için de geçerlidir. Hollywood temelinde ve genel olarak sinemada erkek karakterler, süper kahraman, kaslı, uzun boylu ve yakışıklı olur (Kord ve Krimmer, 2011 :6). Türk melodram filmlerinde de benzer erkeklik sunumları görülmektedir. Temel olarak bu erkeklik sunumu mevcut toplumsal şartlar ve özellikle de ataerkil ideoloji ile de yakından ilgilidir. Aynı şekilde Yeşilçam filmleri tıpkı Hollywood gibi yıldız oyuncu/ star sisteminin hakimiyetindedir. Seyircinin Kadir İnanır, Ediz Hun, Cüneyt Arkın gibi birçok başrol erkek oyuncu için filme gittiği de bir gerçektir. Diğer yandan Yeşilçam döneminde erkeklik temsilleri oyuncular arasında farklılıklar da göstermektedir. Ayhan Işık, Cüneyt Arkın, Kadir İnanır gibi oyuncular "sert erkek" imgesini yaratırken İzzet 
Günay, Göksel Arsoy, Ediz Hun "romantik delikanlı” imgesini yaratırlar (Uluyağcı, 2001: 35-36). Bu açıdan yıldız oyunculara göre bir erkeklik imajı çizildiği ortaya çıkmaktadır. Aynı şekilde başrol erkek karakterin cinsellik olarak sunumları da önemli bir yer arz etmektedir. Yeşilçam filmlerinde başrol erkek karakterler cinsel açıdan mükemmel olarak tanımlanmaktadır (Kabadayı, 2016:172). Cinsellik ve erkeklik olguları düşünüldüğünde filmlerde özellikle erkeklerin cinsel performansları ile öne çıkarıldığı da bir gerçektir. Bu güçlü cinsellik olgusu bir anlamda iktidar sahibi erkeği de vurgulamaktadır. Diğer yandan başrol güçlü erkeğin güzel bir kadın ile evlenmesi ve çocuğunun olması da asli unsurlardandır.

Erkeklik olgusunu etkileyen bir diğer özellik ise anlatılardaki kadınlık temsilleridir. Yeşilçam dönemindeki filmlerde ise kabaca iki kadın temsili bulunmaktadır; bunlar, erkeksi kadın ve hanım hanımcık kadındır (Biryılız, 1993:14). Özgüç'e göre "Aydın Arakon un yönettiği 'Fosforlu Cevriye' ile 'erkek tipli kadın kahramanlar modası' başlar; bu tür filmlerin ilk oyuncusu Neriman Köksal olur” (1990:119). Sezer Sezin'in başrol oynadığı 1959 yapımı Şoför Nebahat da bu türün ilk örneklerindendir. Filmin ana ekseni erkeğin (iktidar sahibi babanın) kaybıdır. Bu durumda Nebahat, yeni iktidar sahibi erkeği bulana kadar gücü eline alır; cinselliği ise ataerkil iktidar tarafından kontrol edilir (Ulusoy, 2015:203). Diğer bir ifade ile dönemin kadınlık sunumları ataerkil düşünce temelinde şekillenmektedir. Yeşilçam filmlerinin en popüler oyuncularından Türkan Şoray dönem içinde baskın olan erkeklik temsillerini şöyle açıklamaktadır: "Biz erkek egemen bir toplumuz ve bu da sinema dünyasına yansıyor. Kadın, daha çok erkek hikâyeleri içerisinde...hep erkek hâkim senaryolara. Erkek kahraman onu kurtarır, bunu kurtarır; kadın kahramanlar ise daha çok hep kaderine boyun eğen, hep ağlayan karakterdedirler" (2011:200). Diğer yandan erkeksi kadın filmlerinin öne çıkması üzerine düşünüldüğünde tekrar erkek iktidarı görülmektedir. Bu erkek kadın tipinin tutmasının nedeni, kadının güvenilmez, zayıf bir yapıda görülmesine karşılık mert, dürüst, cesur olarak tanımlanan erkeksi özellikler kadına yüklendiğinde kadının birdenbire nispi bir güvenilirlik kazanmasıdır (Yücel, 2012:45). Diğer bir deyişle filmlerdeki kadın karakterin, erkeğe ait olduğu düşünülen ya da erkeğe atfedilen özellikler ile toplumsal alanda kabul görmesi sağlanmaktadır. Yeşilçam filmlerinde kadın karakterler ister zengin ve ünlü ister "Şoför Nebahat" gibi erkeksi olsunlar anlatının sonunda sevdikleri erkeğin koruyuculuğu altında iyi bir anne ve ev kadını olmayı istemektedir (Kaplan, 2003:156157). Bu bağlamda Yeşilçam filmlerinde kadının bir şekilde erkeğe intiyaç duyar yapıda yansıtıldığı söylenebilir. Diğer yandan Yeşilçam filmlerinde eğitimli, entelektüel, meslek sahibi kadın da aşağılanan bir güldürü öğesine veya kötülük kaynağına dönüştürülür (Yücel, 2012:49). Bu durumun temel nedeni ise eğitimli ve bilgili kadının, erkeklerin iktidarına bir tehdit olarak algılanmasıdır. Tehdit olarak görülen kadın ise gülünç duruma düşürülerek aşağılanmakta ve erkek hegemonyasının devamı sağlanmaktadır.

Genel olarak Yeşilçam melodramlarında etkin denetleyici erkek ve edilgen denetlenen kadın imgelerinin baskın olduğu söylenebilir (Özsoy, 2004:287). Kadının erkeğin her istediğini yaptığı ve erkeğin kendi arzularına göre yaratılmış bir kadın temsili ile karşılaşılmaktadır. Yeşilçam filmlerinde, kadınlar sevdikleri erkek için savaşmalı; yaptıkları ile erkekleri şaşırtmanın, aşklarını, hayranlıklarını tazelemenin, erkek bakışını 
büyülemenin bir yolunu daima bulmalıdır (Depeli, 2016:132). Bu açıdan Yeşilçam, erkek egemen kültürün filmler yoluyla tekrar tekrar üretildiği, yayıldığı ve yaygıılaştığı ya da meşrulaştığı bir üretim alanıdır (Kırel, 2005: 169).

1970-1980'li yıllarda Türk sinemasında öne çıkan bir olgu erotik filmler/seks filmleridir. Özgüç'e göre seks ve avantürü birleştiren Parçala Behçet (1972) filmi dönemin başlangıcı olarak kabul edilebilir (1990:91). İlerleyen yıllarda ise büyük artış gösteren bu filmler Türk sinema sektörünün neredeyse tamamına egemen olur. Bu dönemin en büyük özelliği erkek seyirciye hitap etmesidir. Cinsellik ve iktidar ilişkisi düşünüldüğünde sosyal yaşamda alt statüde olan erkeklerin bu tür filmler ile içsel dünyalarında eril iktidarlarını yeniden tesis etmeye çalıştıkları söylenebilir. Dönemin yapımlarının ana özelliklerinden birini Demirci şöyle ifade eder "seks filmlerinde erkekler tamamen soyunmaz tamamen soyunanlar hep kadınlardır” (2004:38). Diğer bir ifade bu filmlerde kadın tüketilecek bir cinsel nesne olarak erkeğin bakışına sunulur. Filmlerde erkeğin hem kas gücünü hem de cinsel gücünü vurgulayan birçok anlatı unsuru bulunmaktadır. 1980 darbesi ile birlikte askeri yönetimin sıkı denetimi sonucu seks/erotik filmler giderek azalır ve biter.

1980'li yıllarda özellikle dünyadaki küresel kapitalizmin Türkiye'ye yansımaları ile birlikte liberal görüşler yaygınlık kazanır. Bu durumun Türk sinemasına da yansımaları olur. Özgüç'e göre Türkan Şoray’ın Mine (1982) filmiyle Türk sinemasında kadın filmleri dönemi başlar (1988:71). Dönemin en önemli yönetmeni ise Atıf Yılmaz'dır. Evren, Yılmaz'ın 1982-1992 arasında kadın odaklı filmlere yöneldiğini belirtir (2006:63). Yılmaz filmlerinde kadınların kimlik arayışını yansıttığını söyler örneğin Dul Bir Kadın'da burjuva bir kadın, Adı Vasfiye'de kasabalı bir kadın, Bir Yudum Sevgi'de ise kırsal kesimden bir kadın kimliğini aramaktadır (Karakaş, 2007:76). Dönemin özgür kadınını başlatan ve simgeleştiren ise Müjde Ar'dır. Ar filmlerinde kadının öpüşmesinin, yatağa girmesinin, sevişmesinin sevginin doğal bir uzantısı olduğu gerçeğini meşrulaştırır (Evren, 2006:63). Türk filmlerinde o güne kadar sadece erkek karakterin cinsel duyguları ön planda tutulurdu. Bu filmler ile birlikte kadının cinsel duygularını öne çıkaran yapımlar da artar (Özgüç, 2008:9). Geçmiş dönemde Yeşilçam filmlerinde rol alan yıldız kadın oyuncular da değişmeye başlar. Müjde Ar>ın gelişiyle artık Türk sinemasındaki "kadın kahramanlar", Hülya Koçyiğitsin, Türkan Şoray`ın ve Fatma Girikıin canlandırdığı, boynu bükük, hakkını arayamayan, baş kaldıramayan, yalnızca erkeklerin oyuncağı olan kişiliksiz kadınlar değildir (Özgüç, 1993:58). Kadın filmleri dönemi ile birlikte Türk sinemasında kendi hür düşünce ve duygularıyla beraber birey olarak hareket eden kadın karakterler kabul görmeye başlar.

Türk sineması 90'lı yılların ikinci yarısından itibaren hızlı bir gelişim gösterir. 2000'li yıllar sonrası dönemde de özellikle bağımsız sinemacılar, auteur yönetmenler öne çıkmaktadır. Bu dönem öne çıkan yönetmenlerin filmlerinde özellikle Yeşilçam melodram filmlerinden farklı erkeklik temsillerinin bulunduğu görülmektedir. 1990’ı yıllardan sonra çekilen Türk filmlerinde erkekler geleneksel rollerinden farklı, başarısız, saplantılı, saldırgan, kendilerini ifade edemeyen, öz güveni olmayan, depresif, yalnız, güçsüz, otoritesini kaybetmiş, mükemmellikten uzak karakterlerdir (Özkan, 2016:135). 
Bu filmlerin temelde erkekleri bir kriz içinde temsil ettiği de söylenebilir.

Aşk Filmlerinin Unutulmaz Yönetmeni'nde (1990) bir zamanların ünlü bir erkek sinemacısı yeni bir çıkış yapmak isterken kendini gülünç duruma düşürür. Filmsel evrende zamanın değerlerine ayak uyduramayan erkek temsili vardır. C Blok'taki (1993) iki erkek figürden biri kaba, iktidarsız ve ruhsal olarak ölü bir koca, diğeri ise ruh hastası genç bir adamdır (Ulusay, 2004:148). Gece, Melek ve Bizim Çocuklar (1993) filminin erkekleri kulüpte çalışan bir travesti, genç bir biseksüel ve orta yaşı bir eşcinseldir (Ulusay, 2004:148). Bu filmde heteroseksüel erkeklere ve erkekliğe anlatı içinde önemli bir yer verilmez. Aynı şekilde cinsel anlamda ataerkil erkeklik krizinin nedenlerinden gösterilen cinsel kimliklerin özgürce ifade edilebilmesi bu döneme rastlar. 1990'lı yıllarda Türk sinemasında, cinsel kimlikler kalıp görünümlerden çıkar ve toplumdan gizlenmezler (Okumuş, 2016:69). Ulusay ise 90'ı yıllarda öne çıkan filmlerde erkek kahramanların genellikle kendini ifade edemeyen, ruhsal olarak ölü, başarısız, saplantılı, paranoyak, saldırgan, iktidarsız, küfürlü konuşan, depresif, suç işleyen ve suçluluk duygusu içinde betimlendiklerini tespit eder (2004:159). Bu durum filmlerdeki erkeklik temsillerinin sorunlu olarak resmedildiklerini kanıtlamaktadır. Özkan ise 90’ı yıllardaki erkeklik krizine örnek olarak: Herşey Çok Güzel Olacak (1998), Nihavend Mucize (1997), Lalelide Bir Azize (1999), Gemide (1999), Duruşma (1999), Dar Alanda Kısa Paslaşmalar (2000) filmlerini gösterir (Özkan, 2016:138). Duruşma filminde iki erkeğin aynı kadın ile evlenmesine rağmen bir türlü cinsel ilişkiye girememelerinin trajikomik hikâyesi anlatılmaktadır. Dar Alanda Kısa Paslaşmalar filminde küçük bir kasabadaki erkek futbol takımı oyuncularının başarısızlık ve kaybediş öyküleri yansıtımaktadır. Lalelide Bir Azize filminde üç erkeğin beceriksiz dolandırıcılık hikâyesi betimlenmektedir. Her Şey Çok Güzel Olacak filminde Altan ve abisi yeteneksiz, her işi eline yüzüne bulaştıran, sakar ve başarısız erkek figürleri olarak yansıtılmaktadır. Gemide filminde bir gemi mürettebatı olan dört erkeğin psikolojik ve cinsel sorunları üzerinden anlatı ilerlemektedir. Diğer yandan bu dönemde Türk sinemasında erkeklik krizi ile bağlantılı olarak babalık krizinden de söz edilebilir. Ulusay, 1990 sonrası filmlerde ikame babalar ve babalık krizi olgularını vurgulamaktadır (2004:151-153). $\mathrm{Bu}$ yapımlarda rol modeli olacak babadan/erkekten yoksun kimselerin yaşadıkları çaresizlik ve yön bulamama hali ön plandadır. Örnek olarak Eşkıya (1996) filminde Baran, Cumali'ye; Gemide filminde kaptan tayfalarına babalık etmeye çalışır (Ulusay, 2004:151)

2000'li yıllardan itibaren ise erkeklik olgusunun problemli yanlarını temsil eden erkek karakterlerin sayısının filmlerde artışı dikkat çekmektedir. Kabadayı, 2000'li yılar Türk filmlerinde erkekleri, hastalıklı, problemli, hiçbir yere ait olamayan tipler olarak betimlemektedir (2016:183). Murat İri, 2011-2015 yılları arasında üretilmiş yirmi Türk filmini erkeklik olgusu temelinde inceler. Bu yapımlarda, alt-orta sınıf genç erkeklerin, çıkışsız, cinselliğini yaşayamayan kendini güvende hissetmeyen, belirsiz ve kaotik bir toplumsal alanda yaşamakta zorlandıklarını tespit eder (İri, 2016:117). Saydam ise aynı şekilde Türk sinemasında 2012 yılında gösterime giren bazı filmlerdeki erkeklik krizi olgusunu vurgular (2013) ve Güzel Günler Göreceğiz, Can, Ateşin Düştüğü Yer, Elveda Katya, Lal Gece, Açlığa Doymak filmlerinde değişik şekillerde erkeklik krizi içindeki karakterlerin yer aldığını belirtir (2013:60-61). 
2000’li yıllardaki Türk filmlerinde güçlü, muktedir, ruhen ve bedenen sağlıklı erkek imajı sarsıntıya uğrar. Erkeklik krizine dair, Yazı Tura (2004) filminde erkek bedeninde bir uzuv kaybı, Jan Jan (2007) filminde erkeğin zihinsel yetersizliği, Kabadayı filminde ise erkeğin bellek kaybı öne çıkan unsurlardır (Kabadayı, 2016:172). Yazı Tura filminde Doğu'da askerlik yaparken bir mayın patlaması sonucu ayağını kaybeden Rıdvan ile duyma yetisini yitiren Cevher'in askerden döndükten sonra toplumda yaşadığı kriz durumu ön plana çıkarıır. Rıdvan, evleneceği kadın kendisini bırakıp yakın arkadaşı ile kaçtığı için intihar eder. Oktan, Yazı-Tura filminde erkeklik krizinin baskın biçimde var olduğunu belirtmektedir (2008:160-165). 2000'li yıllarda popüler, gişede başarı yapmış birçok filmde erkeklik krizine dair unsurlara rastlanılmaktadır. Mustafa Hakkında Herşey (2003) filminde alt sınıftan bir erkeğin hızla zenginleşmesi ile sosyal yaşamı, ailesi ve ruhsal durumundaki bozulmalar anlatının odağındadır. Organize İşler (2005) filmi bir grup erkeğin başarısız dolandırıcılık girişimlerine odaklanır. Babam ve Oğlum (2005) filminde baba ve oğullar arasında yaşanılan sorunlu ilişkiler ön plandadır. Hokkabaz (2006) filminde otoriter erkeklik bağlamında sert bir baba ve boyun eğen oğul temsili bulunmaktadır (Akdoğan, 2016: 188-190). Yüksel, Nefes: Vatan Sağolsun (2009) filminde askerlik temelinde erkeklik krizinin yansımalarını vurgulamaktadır (2013). Kaybedenler Kulübü (2011) filminin, kent yaşamında özgürlük arayışındaki erkekler için, sosyal medyada öne çıkartılan repliklerden biri ise şöyledir: "Kadınların özelliği ne biliyor musun, seni sen yapan özelliklere aşık olup sonra senden o özellikleri almaya kalkıyorlar", filmin ana teması sayılabilecek bu cümle erkeklik krizini de vurgular niteliktedir. Issız Adam (2008) filminde İstanbul'da iş hayatında başarılı olan Alper'in sosyal yaşamında insanlar özellikle de kadınlar ile yaşadığı duygusal sorunlar yer almaktadır. Alper'in bir ilişkiyi yürütecek ruhsal gücü bulunmamaktadır.

2000'li yıllardaki auteur yönetmen ya da bağımsız yönetmen filmlerinde de erkeklik krizine dair unsurlara rastlanılmaktadır. Korkuyorum Anne (2004) filminde hafızasını yitiren ve hayatını nasıl devam ettireceğini bilmeyen ana erkek karakter temelinde anlatıda yer alan kadınların yol göstericiliği hakimdir. Takva (2006) filminde dini değerlerine hassasiyet gösteren, namuslu Muharrem bağlı olduğu tarikatın mali işlerinin başına getirilir ahlaki olarak ters bulduğu eylemleri yapmaya mecbur kalınca baskılanmış olan cinselliği dâhil kötülüğün hazzına yenilip akıl sağlığını yitirir (Kabadayı, 2016:179-180). Nuri Bilge Ceylan'ın Uzak (2002) filminde hem entelektüel anlamda sanatçı bir erkeğin toplumsal alandaki çatışmalı hali hem de taşradan gelen işsiz bir erkeğin kentte yaşadıkları zorluklar anlatının temelidir. Yumurta (2007) filminde ana karakter sara krizi nöbetleri temelinde güçsüz, başarısız erkeklik portresi çizmektedir (Kabadayı, 2016:180). Aynı şekilde Semih Kaplanoğlu'nun diğer filmlerinde de sorunlu bir erkeklik sunumu vardır. Kaplanoğlu'nun Yumurta, Süt (2008) ve Bal (2010) üçlemesinde baş karakterin erkeklikle ilgili sorunlarının temeli babasızlıktır (Aydemir, 2015:26). Demirkubuz'un Yeraltı (2012) filminde büyükşehirde hem arkadaşları hem sosyal hayat hem de kadınlar ile sorunları olan bir erkek betimlemesi bulunmaktadır. Lal Gece (2012) filminde ergenliğe yeni girmiş bir kızla evlenen dedesi yaşındaki bir adam üzerinden vurgulanan "çocuk gelin" sorunu, anlatıda erkeğin gözünden betimlenir ve erkeğin dramı genç kızın korkusuna baskın gelir (Saydam, 2013:60). Diğer yandan bu dönemde özellikle sorunlu baba-oğul ilişkileri anlatılarda belirgin olarak öne çıkar. 
2000'li yıllar Türk sinemasında genel olarak problemli baba-oğul öyküleri, erkeklik krizi ve kurban erkeklerin hikâyeleri baskındır (Büker ve Öztürk, 2016:222).

2000'li yıllarda erkeklik krizinin farklı biçimlerde baskın olduğu bu filmlerin bir diğer özelliği de gişede başarılı olmaları ve seyirci sayısı bakımından üst sıralarda yer almalarıdır. Bu durum filmlerin öyküleri ve karakterlerinin toplumsal alan ile güçlü bir etkileşim kurduğunu da göstermektedir. Türk sineması temelinde kadınlık ve erkeklik kavramları incelendiğinde özellikle Yeşilçam melodram filmlerinde keskin hatlarla bir ayrım yapıldığı görülmektedir. Diğer bir ifade ile 1990 öncesi Türk filmlerinde genel olarak şablona dayalı kalıplaşmış erkeklik/kadınlık temsilleri olduğu söylenebilir. Çalışmada 2000'li yıllar temelinde ana akım, popüler sinemada erkeklik krizinin baskın şekilde vurgulandığı $A c ı$ Aşk filmi incelenecektir.

\section{Araștımanın Metodolojisi}

Türk sinemasında erkeklik olgusunun incelendiği çalışmalarda son zamanlarda önemli bir artış görülmektedir. Bu araştırmalarda erkeklik krizi olgusu öne çıkmaktadır. Çalışmada, Türk toplumundaki erkeklik, erkeklik krizi olguları Yeşilçam ve 2000'li yıllar sonrası Türk sineması temelinde Acı Aşk (2009-Taner Elhan) filmi özelinde karşılaştırmalı olarak analiz edilecektir. Acı Aşk filmindeki erkeklik ve erkeklik krizi temsilleri anlatı temelinde karakterler özelinde çözümlenecektir.

Genel olarak Türk sinemasında 2000'li yıllar sonrası dönem, sanat sineması/bağımsız yönetmenler (örneğin Nuri Bilge Ceylan, Zeki Demirkubuz) ve yüksek gişe hasılatına sahip, ticari filmler olarak ikiye ayrılabilir. Bağımsız filmler toplumsal konulara eleştirel yaklaşımları ile dikkat çekerken ticari filmler daha çok eğlendirme işlevi görür. 2000 sonrası Türk sinemasında ana akım film evreni arasından erkeklik krizini anlatısında temel alan filmler araştırıldığında çok eser bulunmamaktadır. 2000'li yıllardaki ticari filmlerin gişe hasılatı incelendiğinde komedi filmlerinin ilk sıralarda yer aldığı söylenebilir. Diğer yandan güçlü, iktidar sahibi, her şeye kudreti yeten erkek kahraman filmleri de hem sayıca fazla hem de gişe de üst sıradadır. Örneğin Kurtlar Vadisi Irak (2006), Son Osmanlı Yandım Ali (2007), Pars Kiraz Operasyonu (2007), Muro Nalet Olsun Içimdeki Insan Sevgisine (2008), Kurtlar Vadisi: Gladio (2009), Recep Ivedik film serisi öne çıkmaktadır. Çalışmada Acı Aşk filmi ana akım, ticari sinemada "erkeklik krizi" olgusunu temel alan ender örneklerden olması bakımından seçilmiştir.

2000'li yıllar başlarında gişede başarılı Türk filmleri incelendiğinde Organize Iş̧ler (2005), Dondurmam Gaymak (2005), Sınav (2006), Beyaz Melek (2007), Neşeli Hayat (2009), Güneşi Gördüm (2009), Maskeli Beşlerserisi eserlerine rastlanır. Bu yapımlarda genellikle alt gelir grubundan kimselerin hikâyeleri baskın olarak görülmektedir. Dönem içinde görece üst gelir grubundan bir insanın hikâyesini erkeklik ve erkeklik krizi kavramı temelinde anlatan nadir filmlerden biri $A c ı$ Aşk'tır. Diğer yandan tanımlanan özelliklere görece uyan Issız Adam (2008) filmi hakkında ise birçok çalışma ve yazı vardır. Buna karşın Acı Aşk filmi hakkında akademik bir çalışma bulunmamaktadır. Bu bağlamda 
amaca yönelik örneklem ile film belirlenmiştir. Araştırmada nitel film analizi yöntemi ve betimleme tekniği kullanılmıştır. Araştırma genelleme yapma amacı taşımamakta Acı Aşk filminin Türk sinema tarihi içindeki erkeklik imajı, erkeklik krizi kavramlarına yaklaşımındaki farklıı̆̆ı veya benzerliği ortaya koymaya çalışmaktadır.

\section{Acı Așk Filmin Özeti:}

Orhan (Halit Ergenç) üniversitede edebiyat profesörüdür. Ayşe (Songül Öden) ve Orhan sevgilidir. Ayşe'nin kendisini aldatmasıyla Orhan bunalıma girer. İstanbul'a giden Orhan burada fotoğrafçılık yapan Oya (Cansu Dere) ile evlenir. Evlendikleri gün araba ile kaza geçirirler ve Oya kör olur. Orhan yine bir krize girer. Bundan sonra üniversiteden öğrencisi Seda (Ezgi Aşaroğlu) ile ilişki yaşamaya başlar. Ayşe pişman olur ve Orhan'a yakın olmak için Oya ile Orhan'ın dairesinin karşısına taşınır. Orhan ile Ayşe arasında yeniden bir ilişki başlar. Seda kendisiyle ilgilenmemesi nedeniyle Orhan'dan intikam alma planları yapar. Oya'nın başarılı bir ameliyatla gözleri açılır. Orhan ve Oya yeniden bir yakınlaşma içine girer. Orhan Ayşe'yi, Oya'da Seda'yı öldürerek yaşamlarına beraber devam eder.

\section{Acı Așk Filminde Erkeklik ve Erkeklik Krizi Olgularının İncelenmesi}

AcıAşkfilminin anlatısı incelendiğinde erkek karakter olarak öne çıkan sadece Orhan'dır. Orhan, ekonomik durumu iyi, yakışıklı, karizmatik, eğitimli, üniversitelerde ders veren biridir. Diğer yandan anlatıya istek ve arzularına göre yön veren tek karakterdir. Bu bağlamda hikâyenin ana yürütücü unsurunun erkek olarak Orhan olduğu söylenebilir. Filmin anlatısının başında, Orhan ve Ayşe birbirlerini sevmektedir. Orhan evlilik teklif etmek için aldığı tek taş yüzük ile birlikte eve geldiğinde Ayşe'yi başka bir erkek ile cinsel ilişki halinde bulur. Orhan aldatılmak için bir neden bulamamaktadır. Bu durum ana erkek karakterin iç dünyasında kendi cinsel başarısı ve performansı hakkında bir takım sorular sormasına neden olur. Diğer bir ifade ile Orhan için erkeklik krizinin başlamasının ana nedeni Ayşe'nin onu aldatmasıdır. Bu olay erkekliğin özellikle cinsellik temelinde yetersizliği fikrini oluşturur. Orhan karakterini oynayan Halit Ergenç anlatıdaki erkeğin durumunu şöyle betimlemektedir: "Orhan Ayşe'den bu darbeyi yemeseydi hiç böyle aldatan, üç kadını aynı anda idare etmeye çalışan, kötülük yapmaktan çekinmeyen bir adam olmazdı... Evli barklı, çoluklu çocuklu, Ayşe'ye sadık bir adam olarak sürdürürdü hayatını." (Ergenç, 2009). Ergenç'in ifadesi ile filmde erkeklik krizinin en temel nedeni kadın tarafından aldatılmaktır.

Ayşe'nin kendisini aldattığını öğrendikten sonra, Orhan özel bir üniversiteye iş başvurusunda bulunur ve mülakata girer. Jürinin söylediği "kendinize güveniniz tam olmalı" cümlesine başı önde ağlayarak, cevap veremez. Bu açıdan Ayşe'nin kendisini aldatması nedeniyle erkeklik krizine girdiği ve kendine güveninin olmadığı daha net ortaya çıkmaktadır. Orhan iş görüşmesinin ardından ağlamaya devam eder. Fotoğrafçılık yapan Oya, Orhan'ın ağlarken fotoğraflarını çeker ve : "uzun zamandır ağlayan bir erkek görmemiştim” der. Bu cümle bir yandan Orhan'ı naif, 
hassas ve duygusal bulmakta diğer yandan ise Orhan'ın güçsüzlüğüne, ezikliğine de vurgu yapmaktadır. Oya, Orhan'ı ağlarken gördüğünde, bir erkeğin ağlamasının tek sebebinin "kadın tarafından aldatılmak" olabileceğini belirtir. Bu söylem de filmin anlatısı içinde erkeklik krizinin temel belirleyicisinin kadın ve cinsellik olduğu vurgusunu güçlendirmektedir. Diğer bir deyişle kadın ve kadın cinselliği üzerinde otorite kuramayan ya da otoritesini kaybeden erkek, güvensizlik duygusu içinde nasıl hareket edeceğini bilemez bir duruma gelmektedir. İş görüşmesinde tanışan Orhan ile Oya daha sonra birlikte lüks bir restoranda yemek yemeye giderler. Oya ekonomik durumunun kötü olması sebebiyle çekingen davranır. Orhan ise "rahat ol benim çok param var" diyerek kadını sakinleştirir. Orhan'ın yaşadığı erkeklik krizi varlıklı olması sebebiyle yatışabilmektedir. Bu durum ekonomik güç ile erkeklik iktidarı ve özgüveni arasındaki karşılıkı ilişkiyi de ortaya koymaktadır.

Orhan temel olarak sessiz, güçsüz, sakin bir erkek portresi çizmektedir. Bir konuşmalarında Oya'nın:" daha yeni aldatılmış bir erkek bana hiç zarar veremez" sözleri de kriz içindeki erkekliğin güçsüzlüğünü vurgulamak yanında temel olarak erkeklerden korkulması gerektiğini de betimlemektedir. Diğer yandan Orhan'ın krizdeki erkekliği, güçsüzlüğü ve kırılganlığı yanında bir kadına sığınma isteğini de beraberinde getirmektedir. Bu bağlamda Orhan, aldatılmanın erkekliğine vurduğu darbeyi genç ve güzel bir kadın olan Oya ile evlenerek onarmaya çalışır. Böylece Orhan geçmişinde onu küçük düşüren Ayşe'nin aldatmasını unutur.

Çift evlendikleri gün trafik kazası geçirir. Kaza dolayısıyla Oya'nın gözleri dışında herhangi bir uzvunda ya da organında bir hasar meydana gelmemiş özellikle fiziksel görünümünde hiçbir şekilde değişiklik olmamıştır. Kazadan sonra Oya cinsel olarak beraber olmak istese de Orhan bunu istememektedir. Karısı artık cinsel yönden ona çekici gelmemektedir. Bu durumun nedeni sorgulandığında kadının kör olması sonucu çıkmaktadır. Orhan'ın kendi kurguladığı içsel erkeklik özelliklerine göre Oya cinsel ilişkiye girilecek değerde değildir. Diğer bir ifade ile Oya ile yaşanılacak herhangi bir ilişki Orhan'ın içsel dünyasında iktidarını kurmaya yetmez. Kültür tarafından oluşturulan erkeklik imajını Orhan yürütmeye çalışır. Bu bağlamda erkeklik, bir kurgudur ama erkekler bu kurguyu yaşamaya çalışırlar (Segal, 1993:630). Bu kurgulanmış erkekliği yaşayamadıkları zaman ise erkekler psikolojik olarak açmaza girerler. Çünkü erkeklik her zaman kanıtlanmaya ihtiyaç duyulan sonsuz testler kümesidir (Kimmel, 2008:51). $\mathrm{Bu}$ bağlamda sosyal yaşam alanı içerisinde erkeklerin karşılaştığı her durum bir sınanma olarak algılanmaktadır. Diğer bir ifade ile Oya'yı elde ederek erkeklik krizini yatıştıran ve eril iktidarını kendi dünyasında yeniden tesis eden Orhan, Oya'nın kör olması ile yeni bir eril kanıtlama sınavına girer. Erkek olarak "yanına yakışan”, "engeli olmayan", "kendine layık olan", toplumsal alanda onu temsil edebilecek kadar güzel, sağlıklı bir kadın beklentisi içindedir. Buna karşın Oya, Orhan olmadan kendi başına sosyal hayatta zorlanmaktadır. Diğer yandan kör bir kadın ile beraber olmayı Orhan toplumsal alanda da erkekliği ve iktidarı üzerine bir darbe olarak görmektedir. Bu açıdan Oya'nın kör olması ile yeni bir süreç başlar; özgüvenini kaybetmiş biçimde Orhan yeniden ağlamaya başlar. Eşi kör olduğu için ağladığı düşünülse de temel olarak bunun sebebi kendinin yeniden düştüğü erkeklik krizi ya da iktidar krizidir. 
Ayşe, çiftin yan evine komşuları olarak yerleşir; Oya ile arkadaş olur, evlerinde vakit geçirmeye başlar. Orhan bu sefer Oya ile yakından ilgilenmeye başlar. Bu durumun ana nedeni ise Ayşe'yi kıskandırmak ve kendisinin terk edilmeyi hak etmeyen bir erkek olduğunu ispatlamaktır. Orhan'ın erkeklik krizinin cinsellikle ile yakından alakalı olduğu savını destekleyen başka bir durum ise Ayşe'nin, Oya ve Orhan'ın evine geldiğinde ortaya çıkar. Yan komşuları olarak kendilerini ziyarete gelen Ayşe'yi gören Orhan, Oya'yı öpmeye başlayarak cinsellik içeren davranışlar sergiler. Ayşe, izin isteyerek odadan ayrılır ama evden çıkmaz; çiftin sevişmesini izler. Orhan asında Oya ile sevişmemekte vücut dili ve bakışları ile Ayşe'ye yönelik kendi erkekliğini dışa vurmakta, cinsel performansını/gücünü sunmaktadır. Ayşe'nin taşınması ve iktidarı altına yeni bir kadının girmesi Orhan'ın erkeklik krizinin de yatışmasını sağlar. Bu arada Orhan, Ayşe'nin de etkisi ile Oya'dan ayrılmak istemektedir. Oya, Orhan'a ayrılmaması için yalvarır; kadının bu güçsüz, ezik hali kocasının iyice ondan soğumasına neden olur. Orhan için kadın onun iktidarını meşrulaştıracak kadar güçlü değildir, diğer yandan ise eril iktidarını ispatlayamayacak kadar zayıftır. Kocasının kendisini istememesi ve kör olmanın psikolojik sorunları ile Oya banyoda bileklerini keserek intihar eder. Bunu gören Orhan üzülmez, heyecanlanmaz, tedirgin olmaz sadece oturup yemeğini yer. Diğer bir anlatımla Orhan, Oya'nın ölmesini istemekte ve bir an önce ölmesini beklemektedir; çünkü onun iktidarını tesis edemeyen bir kadının var ya da yok olması çok önemli değildir. Daha sonra vicdan azabına dayanamaz Oya'yı hastaneye kaldırır ve yaşamasını sağlar.

Orhan üniversitede edebiyat dersleri veren birisidir. Filmsel evrenin başında özellikle kadın partneri (Ayşe) ile ilişkisi yolunda giderken öğrencilerine karşı nazik ve hassastır. Buna karşın kendi özel yaşamında otorite altına alacağı bir kadın partneri olmadığı zaman ise dersteki öğrencilerine özellikle de kadın öğrencilerine karşı agresif ve saldırgandır. Ataerkil kültür tahakkümcüdür; erkeklere hükmetmeyi öğretir (Hooks, 2018:124). Bu durum da erkeklerin karşılarında hükmedecekleri bir unsur arayışına sokar ki genel olarak bu da kadınları baskı altına almaktır. Diğer bir ifade ile Orhan partner olarak ona itaat eden bir kadın olmayınca sosyal alanda kendi kurallarına uyacak kadınlar (öğrencileri) üzerinde otoritesini ve sertliğini arttırmaktadır. Bu duruma örnek olarak otoritesi altında bir kadın olmadığında, derse geç gelen kız öğrencisine sinirlenmesi ve onu derse almaması gösterilebilir; ancak anlatının girişinde geç kalan benzer kadın öğrenciyi derse espri ile aldığı görülmektedir.

Dersten kovduğu öğrencisi Seda şarkıcılık ve oyunculuk yapmaktadır. Kendi sahne aldığı yere Orhan'ı davet eder. Orhan sahnede Seda'yı görünce kamusal yaşamda yeni bir iktidar unsuru kadın ile karşılaşır çünkü sahnede şarkı söyleyen kadın toplumsal alanda bütün hayran bakışları üstünde toplamaktadır. Oya ile dış dünyada kuramadığı iktidarı, otoriteyi Seda ile bulmaya çalışır. İki kadının da kendi peşinde koşmasını sağlayan Orhan bu sefer Seda ile yemeğe çıkmakta ve onu da iktidarı altına almaktadır. Dorsay (2009) Orhan'ın filmde "ilah erkek" olarak gösterildiğini belirtmektedir. Bu bağlamda daha çok sayıda kadın ile ilişkiye girmesi kendi ruhsal dünyasında erkeklik imajının da giderek daha fazla güçlenmesini sağlamakta bununla birlikte kadınlar da Orhan'ı adeta ilahlaştırmaktadır. 
Seda, Orhan'ın erkeklik krizini bir yandan yatıştırmakta diğer yandan ise yeniden ortaya çıkarmaktadır. Orhan'a iktidarını, kararlarını ve davranışlarını sorgulatmakta onu yönlendirmeye çalışmaktadır. Seda'nın: "akşam çıkışta 5 gibi sizi bekliyor olacağım" sözü Orhan'ın arzu ve isteklerine göre yol almayan bir kadın-erkek ilişkisini göstermekte ve Orhan'ı rahatsız etmektedir. Bu durum üzerine Orhan, öğrencisi ile görüşmemeye başlar, aradan birkaç ay geçer. Okulun bahçesinde herkesin içinde Orhan'a saldıran Seda: "Allah belanı versin hayvan herif, hayvansın sen hayvan, ... beni dinleyeceksin neredeydin sen son iki aydır...senin ailen burada" deyip karnını gösterir. Toplumsal alanda Orhan küçük düştüğü gibi ahlaken de yalancı ve kötü olarak gösterilmektedir. Bu durum Orhan'ın iktidarını derinden sarsar. Orhan buna karşılık olarak kadını hayatından çıkarır. Seda ise yaşadığı ilişkiyi Oya ve Ayşe'ye anlatır. Seda'nın: "kabul edersiniz ki kocanız çok yakışıklı, karizmatik, bir de okuldaki havasını bir görseniz, öyle bir heves gibi başladı sonra ben ona aşık oldum" sözleri diğer iki kadını kıskandırdığı gibi Orhan'ın erkeklik değerini de kadınların gözünde yükseltir. Oya da Ayşe de, Orhan'ı aldattığı için suçlamaz. Film bu bağlamda Orhan'ın erişilmez bir erkek olduğu imajını daha da pekiştirir. Aynı şekilde iki kadın, Orhan'ı yeniden kazanmak için mücadeleye girişirler. Bu mücadele sonunda Oya, Seda'yı öldürüp Orhan'ın eşi olacaktır.

Ayşe ve Oya aynı anda hamile kalır. Seda da hamile kaldığını iddia etmektedir. Yavuz'a göre Türkiye'de erkeği bekleyen en son imtihan, evlenerek çocuk sahibi olmaktır (2014: 124). Çocuk sahibi olanın soyunun devamı temelinde erkekliğini ortaya koyduğu düşüncesi hakimdir. Toplumsal alanda çocuk sahibi olmak ile erkeklik arasında kurulan bağ düşünüldüğünde, bu durum cinsellik temelinde, Orhan için güçlü erkek vurgusu olarak da düşünülebilir. Diğer yandan Ayşe "bebeğini düşürdüğü/ kaybettiği için” Orhan'ın kendinden vazgeçeceğini düşünmektedir. Orhan'ın Ayşe'ye karşı güvensizliği anlatının ilerleyen dönemlerinde yeniden ortaya çıkar. Orhan: "bebek benden mi?" sorusu ile iç dünyasında karmaşa yaşamaya başlar. Daha önce aldatılmış olmasının yanında erkekliğine ve iktidarına yapılan darbenin sonucu mafyaya dayak attırarak Ayşe'nin bebeğini düşürmesine neden olur; daha sonra da Ayşe'yi öldürür.

Anlatıdaki karakterlerin aileleri incelendiğinde Oya'nın babası sağır ve dilsizdir. Orhan'ın ailesine yönelik herhangi bir unsura direkt olarak rastlanılmamaktadır. Orhan'ın kendi ifadelerinden az da olsa ailesi hakkında bazı bilgiler edinilebilmektedir. Orhan, İzmirli zengin bir ailenin oğludur; babasının "kalpsiz" olduğunu belirtir. Bu betimleme ise baba ile erkek çocuk arasındaki iletişimsizliği ya da çatışmalı ve kötü ilişkiyi göstermektedir. Aynı şekilde ailesi ile yaşadığı bu sorunlu ilişkinin kendi özel hayatında diğer insanlar ile de sorunlara yol açtığı da söylenebilir. Ayşe ve Seda'nın aileleri ile ilgili anlatıda herhangi bir bilgi verilmemektedir.

Filmdeki kadın karakterler incelendiğinde Ayşe'nin ne iş yaptığı bilinmemekle birlikte varlıklı biri olduğu lüks bir evde kaldığı, son model bir arabaya sahip olduğu görülmektedir. Benzer şekilde Oya fotoğrafçılık yapmakta, kişisel fotoğraf sergileri açmaktadır, sanatçı kişiliği ön plandadır. Diğer yandan Seda da tiyatro ve sahne sanatları ile ilgilenmekte, şarkı söyleyerek, televizyon dizilerinde oynamaktadır. Bu 
bağlamda değerlendirildiğinde anlatıda yer alan bütün kadın karakterlerin eğitimli, modern ve kent kültürüne sahip oldukları ortaya çıkmaktadır. Diğer bir anlatımla erkek ile kendini eşit gören/görmesi gereken bir yapıdadırlar. Ayrıca ekonomik yönden belirli bir gelirin üzerinde oldukları izlenimi oluşmaktadır.

Genel olarak filmsel anlatıda yer alan üç kadın karakter incelendiğinde her birinin de giyim, konuşma, beden dili, öğrenim durumu ve sosyal hayat gibi özellikleri ile şehirli, modern, dışa dönük, eğitimli kimseler olduğu görülmektedir. Kadın karakterlerde gözlemlenen bu durum birçok Türk filminde görülmeye alışılan klasik ev hanımı tiplemesinden de farklıdır. Aynı şekilde her üç kadın da kendilerini ifade eden aktif kimselerdir. Buna karşın erkek iktidarını meşrulaştırma ve otoritesine itaat konusunda ise çok istekli görünmektedirler. Filmsel evrenin temel anlatı dinamiği Orhan'ın girdiği erkeklik krizleri daha sonra çeşitli yollarla bu krizlerden kurtulması tekrar erkeklik krizine girmesi yine kadınlar ve cinsel aktiflik ile bu krizlerden kurtulması şeklinde tanımlanabilir. Orhan'ın iktidarı, "kadınlar eliyle, kadınlar üzerinde ve kadınları kullanarak" devam eden bir otoritedir. Bu açıdan iktidarını sarsan diğer bir ifade ile erkeklik krizine neden olan/olanlar da kadınlardır.

\section{Acı Așk Filminin Yeșilçam Sineması Ile İlișkisi}

Acı Aşk Türk sinema tarihinde Yeşilçam olarak adlandırılan melodram filmleri ile benzerlikler göstermektedir. Acı Aşk filminin yönetmeni Taner Elhan "klişe çok kullanıldığı için klişedir... Peki bir şey niye çok kullanılır? Çalıştığı için...Senaryoda klişe kullanmaktan kaçınmamak lazım...70’ler Türk sinemasının kullandığı klişeleri biraz kazıyınca, insan onları kullanarak farklı bir şeyler yapabileceğini anlıyor." (2009:36) ifadelerini kullanmaktadır. Yönetmenin bu sözleri, filmdeki Yeşilçam anlatı kalıplarının bilinçli şekilde kullanıldığını gösterir. Bununla birlikte senarist Onur Ünlü ve yönetmen Taner Elhan, Yeşilçam'ın bazı özelliklerini kendilerine has yorumlar, modernize edip yeniden sunar. Kerem Akça'da film için "Yeşilçam melodramlarının yapısını tersyüz eden biçimci eser" (2010) tanımlamasını yapmaktadır. Yeşilçam filmleri bağlamında, Orhan yazarlık ile uğraşması, varlıklı ve saygın bir ailenin mensubu olması, sosyal hayatta kibar davranışları ile temel olarak "iyi erkek" davranışları sergilemektedir. Aynı şekilde $A c ı$ Aşk filmi bağlamında değerlendirildiğinde, Yeşilçam'da zengin, eğitimli, iyiliksever erkek karakteri sıklıkça yer almasına karşın bu erkeğin bir kadın tarafından aldatıldığı nerdeyse hiç görülmemiştir. Zengin ve yakışıklı erkek ile ona ulaşmaya çalışan fakir kızın aşkı ya da tam tersi durum ise sıklıkla yer almıştır. Orhan ve Oya'nın evliliği fakir kimsesiz, kör kız ile zengin, yakışıklı erkeğin evlenmesini andırmaktadır.

Yeşilçam özelinde başrol oynayan erkekler genel anlamda güçlü, yakışıkı, mağdurun yanında kötünün karşısında betimlenmektedir. Acı Aşk filminde ise Orhan aldatan, kötülük yapan, insan öldüren bir erkek portresi çizmektedir. Diğer yandan erkek karakterin kötülüğünün nedeni olarak "kadının aldatması" öne çıkarılmaktadır. Bu aldatma erkeğin yaptığı her şeyi meşrulaştıran bir unsur vazifesi de görmektedir. Filmde Orhan temel olarak iyi bir karakter olarak betimlenmemektedir. Buna karşın 
filmin sonunda Oya ile birlikte mutluluk içinde resmedilmektedir. Yeşilçam'da mutlu sonlar iyi insanların ulaştıkları bir durum iken $A c ı$ Aşk filminde kötü bir erkek ve katil bir kadın ile kurulan bir çekirdek aile görülmektedir.

Oya, Yeşilçam film klişelerine en uygun kadın tipidir. Vardan'a göre de Oya Yeşilçam geleneğine uygun bir tiplemedir (2009). Diğer bir ifade ile Oya, anlatıda "iyi kalpli", "mağdur" ve "ezilen" kadındır. Orhan'ın zor durumunda, ona yardım eden, kaza sonucu kör olan, Orhan'ın psikolojik baskıları ile intihar eden, aldatılan ve ailesini bir arada tutmak için insan öldürmek dâhil her türlü fedakârlığa katlanandır. Orhan tarafından kötü muameleye uğramasına ve aldatılmasına rağmen Orhan'ı sonuna kadar destekleyendir. Genel olarak Türk sineması incelendiğinde iki kadın arasında kalmış erkek karakterler sıklıkla görülmektedir. Bu şablonda kadınlardan biri iyi, masum iken diğeri kötü ve zarar verendir. Bu genelleme temelinde Ayşe, evlenmek üzere olduğu erkeği aldattığı için kötü olandır. Ataerkil kültürde aile reisliği erkekliğin iktidar konumunu onaylayacak ve destekleyecek kadının varlığına ihtiyaç duyar (Sancar, 2016:67). Erkeğin iktidarını onaylayacak kişiler olmayınca psikolojik olarak bir sarsıntı içine girer. Bu bağlamda Oya ise en kötü zamanında erkeğin yanında olduğu için iyi kadındır.

Orhan ve Oya evlendikten sonra araba ile yolda giderken aniden kaza yaparlar. Arabanın kaza sahnesi, Yeşilçam filmlerindeki gibi, gerçekçilikten uzak çekim/kurgu özelliklerine sahiptir. Kazanın ardından bedensel olarak iyi ama kör olan başrol kadın karakter ise Yeşilçam filmlerinde sıklıkla kullanılan bir tiplemedir. Yeşilçam'da kör olma herkesin yardım ettiği, elinden tuttuğu, yol gösterdiği bir davranışlar kümesini ifade eder. Ancak Orhan kör olduğu için Oya'yı istememektedir. Diğer yandan Oya'nın “Isviçre'den göz ameliyatı için güzel haberler var” sözleri ile yurtdışında ameliyat olma hali de Yeşilçam filmlerinde sıkça yer verilen unsurlardandır.

Orhan anlatıdaki bütün kadınlar ile cinsel birliktelik yaşamıştır. Bu durum da Yeşilçam filmlerindeki başrol erkek karakterinin özellikleri ile ters düşmektedir. Yeşilçam erkek başrolleri her ne koşulda olursa olsun sevdikleri ya da evli oldukları kadın dışında başka birisi ile ne cinsel ne de duygusal bir ilişki yaşamayı isterlerdi.

\section{Sonuç}

Erkekler özellikle ataerkil ideolojinin/kültürün kendilerine sağladıkları avantajlardan yararlanır. Son yıllarda kamusal alanda ve iş yaşamında kadının daha çok yer alması ataerkil düzende ve erkeklik iktidarında bir takım aşınmalara yol açar. Genel olarak erkekliğin krize girdiği bir takım sıkıntılar ve sorunlar ile baş etmek zorunda kaldığı çalışmalarda dile getirilen bir özelliktir.

Son zamanlarda Türk filmleri üzerine yapılan çalışmalarda erkeklik ve erkeklik krizi olgularına sıklıkla rastlanmaktadır. Acı Aşk filminin anlatısı bu kavramlar temelinde yol almaktadır. Diğer yandan film, Yeşilçam melodramlarının bazı anlatı ve karakter 
özelliklerini kendine has bir biçimde kullanır. Bu açıdan eser Yeşilçam Türk filmleri ile kadın ve erkek karakterlerin temsili temelinde bir takım benzerlikler/farklııklar içermektedir. Orhan, Türk sinemasında erkeklik krizi içindeki film kahramanlarının genel tipolojisinden farklılık göstermektedir. Bugüne kadar ki Türk sinemasında erkeklik krizi ya da eril krize anlatılarında yer vermiş filmler incelendiğinde genellikle başrol erkek karakterin alt gelir grubundan, eğitimsiz, kaba, sanat ve kültüre ilgisi olmayan tipler olduğu göze çarpmaktadır. Bunların aksine Orhan ise zengin, eğitimli, nazik, sanattan anlayan bir yapıya sahiptir. Diğer bir anlatımla şimdiye kadar genel olarak Türk sinemasında erkeklik krizi içinde işlenmemiş ya da çok az yer verilmiş bir kişiliktir.

Türk sinema tarihi Yeşilçam döneminden itibaren modernleşen kadınları ve erkekleri ön plana alır. Acı Aşk filminde ise eğitim seviyesi yüksek, toplumsal alanda saygınlığı olan, bilgili ve entelektüel yani modern bir erkeğin de ataerkil yapının imtiyaz ve otoritesinden sonuna kadar faydalanma isteği göze çarpmaktadır. Bu açıdan maddi anlamda modernleşen ve ilerleyen toplumsal yapı, fikri ve düşüncesel anlamda ise eril iktidar kodlarını yaşamaya ve yaşatmaya devam etmektedir. Aynı şekilde filmin kadın karakterleri de dış görünüşleri, yaptıkları meslekler ile modern bir görüntü çizerken erkeğe karşı davranışlarında pasif ve itaatkârdır. Bu durum modernleşmenin ve ilerlemenin yeterince etkili olmadığı fikrini de düşündürtmektedir.

Acı Aşk filmi erkeklik krizinin nedeni ve bu erkeklik krizinden çıkış yollarını betimlemesi bakımından önem arz etmektedir. Filmde erkeklik krizinin en önemli göstergesi Orhan karakterinin özellikle kadınlar üzerinde iktidarını ve gücünü kaybetmesidir. Orhan karakteri incelendiğinde yaşam alanı içinde başta kadın arkadaşları olmak üzere eşyaları, öğrencileri vb. kendi dışında her şeyi belli bir düzen içinde yapılandırma isteği görülmektedir. Bu istek kendi istediği biçimde gerçekleşmezse Orhan'ın erkeklik imajı bir krize girmektedir. Diğer yandan Yeşilçam filmlerinde kadın karakter her ne şartta olursa olsun erkeğin isteklerini ve istediklerini yaptığı için herhangi bir eril krizden söz edilemezdi. Film anlatısında erkeklik- güç ilişkisi bazı noktalarda kas gücünü ifade etmektedir. Bu açıdan kendisini aldatan Ayşe'yi evinde tartaklaması, Seda'nın arkadaşı olan ve Orhan ile dalga geçmeye çalışan erkeği dövmesi bu duruma örnek gösterilebilir. Yeşilçam filmleri genelinde de başrol erkek karakterin kuvvetli olduğu ve kavgalarda birçok kişiyi dövdüğü görülmektedir.

Cinsellik ve iktidar arasındaki ilişki düşünüldüğünde krizin temeli Ayşe ile başka bir erkeğin cinsel ilişkisidir. Bu açıdan Orhan'ın ruhsal dünyasında kendisinin cinsel olarak çekici ya da yeterli gelmediği imajı oluşmaktadır. Anlatının ilerleyen bölümlerinde Oya, Ayşe ve Seda ile sürekli cinsel ilişki kurma isteği geçmişten gelen bu yetersizlik imajından da kaynaklanmaktadır. Diğer bir anlatımla cinsellik üzerinden yeniden inşa ettiği iktidarı, erkeklik krizini yatıştırmaktadır. Yeşilçam filmlerinde ise başrol erkek karakterlerin kusursuz cinsel performansları vardır. Bu bağlamda cinsellik olgusu Yeşilçam filmlerinde eril iktidar krizlerine sebep olmamaktadır. Öte yandan kadınlar Orhan'ın isteklerine ve arzularına göre hareket ettiklerinde herhangi bir sorun görünmemektedir. Ancak tersi durumda Orhan'ın ruhsal durumu kötüleşmekte krize girmektedir. Yeşilçam filmlerinin genelinde ise kadının, erkeğin istek ve arzularına göre 
hareket etmemesi ender görülebilecek bir durumdur. Örneğin istisnai olarak kadın başrol karakter iyilik temelinde birisini ya da bir şeyi korumak amacıyla erkek karakterin söz ve davranışlarına karşı çıkabilirdi.

Yeşilçam filmlerinde başrol erkek karakterlerin ağlayarak duygularını dışarıya vurmaları çok rastlanan bir durum değilken Acı Aşk filminde erkek karakterin acıklı duygu durumunu defalarca abartılı olarak sergilediği görülmektedir. Yeşilçam filmlerinde olduğu gibi $A c ı$ Aşk filminde de kadın karakterin düşünce dünyasında erkeğe bir çocuk verememenin yarattığı sıkıntı da bulunmaktadır.

Yeşilçam filmlerinde kadın karakterin birisini öldürmesi özellikle namusunu korumak bağlamında değilse sık rastlanıımayan bir durumdur. Filmdeki kadın karakterin, kendine rakip kadını öldürmesi temel olarak eril iktidar ve güç ilişkilerinden çok fazla etkilendiğini de ispatlamaktadır. Aynı şekilde Yeşilçam filmlerinde kötü kadın karakter anlatının sonunda iyiliğe doğru evrilir, yaptıklarından pişman halde iyilerin bir araya gelmesini sağlardı. Acı Aşk filminde ise temel olarak hangi karakterin iyi ya da kötü olarak sınıflandırılacağı belli değildir. Filmin en iyi karakteri denilebilecek Oya, etrafındaki kötülüğe göz yumacak kadar erkeğin iktidarını kabul eder. Anlatının sonunda iyilerin mutlu olması değil erkeğe sadakati fazla olan kadının mutlu olması bulunmaktadır.

Filmsel evrende temel olarak kadınların (Ayşe, Oya ve Seda) pasif oldukları söylenemez Yeşilçam filmlerinde ise kadın karakterlerin daha çok sessiz, olan biteni kabul eden görüntüsü vardır. Diğer yandan kadın karakterlerin yaptıkları eylemlerin çoğunun Orhan'a kendilerini beğendirmek, Orhan'ı elde edebilmek için gerçekleştirdikleri ortaya çıkmaktadır. Bu açıdan kadınların yaptığı eylemlerin Orhan'ı daha da güçlendirdiği görülmektedir. Orhan Ayşe'nin üzerinde iktidarını sağlayamadığı için bir krize girer. Orhan erkeklik krizinden yine bir kadın olan Oya'yı elde edince kurtulur. Oya'nın kör kalması sonucu oluşan krizi de öğrencisi ile giderir. Oya'nın sağlıklı duruma gelmesi ile diğer iki kadın anlatının dışında bırakılır. Bu bağlamda erkeklerin iktidarı kaynağı kadınlar olmaktadır. Kadınların beraber, birlikte hareket edememeleri eril iktidarı güçlendirmektedir.

Sinema filmleri her ne kadar kurgusal bir anlatıya dayansa da bulunduğu toplumsal yapıdan da izler taşır. Diğer bir ifade ile filmsel evren toplumdaki sorunların, iliş̧kilerin, değişimlerin yansıtıldığı bir alandır. Acı Aşk filmi özelinde Türkiye toplumunda özellikle eril krizin yayılarak üst gelir grubundaki erkekleri de etkilediği ya da etkileyebileceği sonucuna varılabilir. Öte yandan Yeşilçam film karakterlerinin bilinçaltında yatan ve sürekli onları denetleyen ataerkil ideolojinin 2000'li yılların başındaki Acı Aşk filminde de sürdüğü ortaya çıkmaktadır. Yeşilçam filmleri kabaca 1950-1970 arasında birbirlerini taklit eden, şablona dayalı bir anlatının ürünleridir. Aradan on yıllarca geçmesine rağmen senaristin, yönetmenin ya da yapımcının düşünce dünyasında Yeşilçam döneminin referanslarının, kodlarının olması toplumsal değişimin ve dönüşümünün kişilerin düşüncesel evreninde çok da hızlı olmadığını da gösterebilir. 


\section{Kaynakça}

Aboim, S. (2010). Plural Masculinities The Remaking of The Self in Private Life. Burlington: Ashgate Publishing.

Akça, K. (2010). Minimalist Sinemanın Miyadı Doldu mu? http://www.haberturk.com/kultur-sanat/ haber/508592-minimalist-sinemanin-miyadi-doldu-mu. Erişim Tarihi: 07.08.2018

Aydemir, G. (2015). Sinemada Değişen Erkeklik Tipleri: Sinir Krizinin Eşiğindeki Erkekler. Film Arası Dergisi,47, 24-26.

Biryıldız, E. (1993). Şoför Nebahat mi Olalım Hanımefendi mi?. Marmara Illetişim Dergisi, 4, 5-18

Boratav, H. B. Fişek, G. O. ve Ziya, H. E. (2017). Erkekliğin Türkiye Halleri. İstanbul: Bilgi Üniversitesi Yayınları.

Bourdieu, P. (2015). Eril Tahakküm. (Çev. B. Yılmaz). İstanbul: Bağlam Yayıncılık.

Bozok, M. (2011). Soru ve Cevaplarla Erkeklikler. İstanbul: Sogep Yayınları.

Bozok, M. (2018). Ebeveynlik, Erkeklik Ve Çalışma Hayatı Arasında Türkiye'de Babalık. İstanbul: Açev Yayınları.

Büker, S. ve Öztürk, R. (2016). Mutlu Son'dan Abluka'ya Türk Sineması. L. Özgenel (Ed.) Sanat Üzerine Okumalar 60 Yıla Bakış. İçinde (s.197-240). Ankara: Odtü Yayıncılık.

Cengiz, K. \&Tol, U. U. \&Küçükural, Ö. (2004). Hegemonik Erkekliğin Peşinden. Toplum ve Bilim, 101, 50-70.

Connell, R.W. (2000). The Men and The Boys . New South Wales: Allen \& Unwin.

Connell, R. W. (2005). Masculinities. Los Angeles: University of California Press.

Depeli, G. (2016). Emine Mine, Hepsi Sensin Be Kızım-Yeşilçam Sinemasının Eril Fantezisi. Fe Dergi, 8(2), 125-137.

Demirci, C. (2004). Araya Parça Giren Yıllar. İstanbul:İnkilap Kitabevi.

Dorsay, A. (2009). Eleştirmenler Hem 'Acı' Hem 'Tatlı'. http://www.milliyet.com.tr/elestirmenlerhem--aci--hem--tatli--magazin-1173927/. Erişim Tarihi: 08.08.2018

Dökmen, Z. Y. (2016). Toplumsal Cinsiyet Sosyal Psikolojik Açıklamalar. İstanbul:Remzi Kitabevi.

Elhan, T. (2009). Acı Aşk Klişenin Kazınmış Kısmı. (Söyleşi: B. Göl) Altyazı Dergisi, 90,36-37.

Ergenç, H. (2009). 'Acı Aşk' ilişkileri sorguluyor. http://www.hurriyet.com.tr/kelebek/aci-askiliskileri-sorguluyor-13239868. Erişim Tarihi: 09.08.2018

Erkılıç, H. (2011). Türk Sinemasında Hegemonik Erkek(Lik): Kahramandan Anti-Kahramana Erkeklik Temsil(Ler)i. i. Erdoğan (Ed.) Medyada Hegemonik Erkek(Lik) ve Temsil. İçinde (s.231242). İstanbul: Kalkedon Yayınları.

Ertürk, Y. (2015). Prof. Dr. Yakın Ertürk: Erkeklik 40 yıldır krizde. http://www.karar.com/gundemhaberleri/prof-dr-yakin-erturk-erkeklik-40-yildir-krizde. Erişim Tarihi: 11.08.2018

Evren, B. (2006). Usta ya da Her Devrin Adamı. K. Özyazıcı (Haz.) Adı: Atıf Yılmaz . İçinde (s. 
53-70). Ankara: Dost Kitabevi Yayınları.

Frosh, S.; Phoenix, A. ve Pattman, R. (2002). Young Masculinities Understanding Boys in Contemporary Society. New York: Palgrave.

Ging, D. (2013). Men and Masculinities in Irish Cinema. New York: Palgrave Macmillan.

Goldberg, H. (2018). Erkek OImanın Tehlikeleri. (Çev. S. Budak). İstanbul: Totem Yayınları.

Güçhan, G. (1992). Toplumsal Değişme ve Türk Sineması. Ankara: İmge Kitabevi.

Hearn, J. (2004). Men, Fathers And The State: National And Global Relations. B. Hobson (Ed.) Making Men into Fathers Men- Masculinities and The Social Politics of Fatherhood. İçinde (s.245272). Cambridge: Cambridge University Press.

Hobson, B. ve Morgan, D. (2004). Introduction: Making Men into Fathers. B. Hobson (Ed.) Making Men into Fathers Men- Masculinities and The Social Politics of Fatherhood. Içinde (s.1-24). Cambridge: Cambridge University Press.

Hooks, B. (2018). Değişme İsteği Erkekler, Erkeklik ve Sevgi. (Çev. Z. Kutluata). İstanbul: Bgst Yayınları

Hooper, C. (2001). Manlystates Masculinities, International Relations, And Gender Politics. New York: Columbia University Press.

Ingram, N. ve Waller, R. (2014). Degrees of Masculinity: Working and Middle-Class Undergraduate Students' Constructions of Masculine Identities. S. Roberts (Ed.) Debating Modern Masculinities: Change, Continuity, Crisis?. İçinde (s.35-51). New York: Palgrave Macmillan.

İri, M. (2016). Türk Sineması'nda Erkeklik Performansları. İstanbul: Derin Yayınları.

Kabadayı, L. (2016). İyi Adam-Kötü Adam Son Dönem Türk Sinemasında Erkek Karakter ve Stereotipleşme. H. Kuruoğlu (Ed.) Erkek Kimliğinin Değişe(Meye)N Hâlleri. İçinde (s.167-191). İstanbul: Nobel Yayınevi

Kaplan E. A. Women And FIIm Both Sides Of The Camera 1983 Taylor \& Francis E-Library, 2001. New York London

Kaplan, F. N. (2003). Toplumsal Konumu ve Bu Konumun Değişimiyle Türk Sinemasında Kadın. İstanbul Ticaret Üniversitesi Sosyal Bilimler Dergisi, 2 (4),149-173.

Karakaş, B. (2007). Kadın Filmi Diye Bir Şey Yoktur-Atıf Yılmaz’la Söyleşi. M. Arslan (Der.), Rejisör Atıf Yılmaz (s. 74-80). İstanbul:Agora Kitaplığı.

Kırel, S. (2005). Yeşilçam Öykü Sineması. İstanbul: Babil Yayınları.

Kimmel, M. ve Aronson, A. (2004). Men and Masculinities- Social, Cultural, and Historical Encyclopedia Volume I. California: Abc-Clio.

Kimmel, M. (2008). Guyland The Perilous World Where Boys Become Men. New York:Harper Collins.

Kimmel, M.S. ve Messner, M. A. (2010). Men's Lives. Boston: Allyn \& Bacon.

Kord, S. ve Krimmer, E. (2011). Contemporary Hollywood Masculinities Gender, Genre, And 
Politics. New York: Palgrave Macmillan.

Leonard, S. (2014). Escaping The Recession? The New Vitality Of The Woman Worker. D. Negra ve Y. Tasker (Ed.) Gendering The Recession Media and Culture in an Age of Austerity. Içinde (s.31-58). London: Duke University Press.

Lotz, A. D. (2014). Cable Guys Television and Masculinities in The Twenty-First Century. New York: New York University Press.

Mora, S. (2006). Cinemachismo Masculinities and Sexuality in Mexican Film. Austin: University of Texas Press.

Nayak, A. ve Kehily, M. J. (2013). Gender, Youth and Culture- Global Masculinities and Femininities. New York: Palgrave Macmillan.

Oktan, A. (2008). Türk Sinemasında Hegemonik Erkeklikten Erkeklik Krizine Yazı-Tura ve Erkeklik Bunalımının Sınırları. Selçuk Üniversitesi Iletişim Fakültesi Akademik Dergisi,5 (2), 152-166.

Okumuş, F. (2016). 2000’li Yıllarda İki Türk Filminde Görünen Cinsellik: Zenne ve Çekmeceler. S. Serter (Ed.) Yeni Kadrajlar Türkiye’de Sinema. İçinde (s. 67-78).Ankara: Deki Basımevi.

Onur, H. ve Koyuncu, B. (2004). Hegemonik Erkekliğin Görünmeyen Yüzü: Sosyalizasyon Sürecinde Erkeklik Oluşumları ve Krizleri Üzerine Düşünceler. Toplum ve Bilim,101,31-49.

Özbay, C. ve Baliç, İ. (2004). Erkekliğin Ev Halleri. Toplum ve Bilim,101,89-103.

Özgüç, A. (1988). Kronolojik Türk Sinema Tarihi 1914-1988. İstanbul: Kültür ve Turizm Bakanlığı Yayınları.

Özgüç, A. (1990). Başlangıcından Bugüne Türk Sinemasında Illkler. İstanbul: Yılmaz Yayınları.

Özgüç, A. (1993). 100 Filmde Başlangıcından Günümüze Türk Sineması. Ankara:Bilgi Yayınevi.

Özgüç, A. (2008). Türk Sinemasının Kadınları. İstanbul: Agora Kitaplığı.

Özkan, Z. Ç. (2016). Geleneksel Türk Sinemasında Erkeğin Değişen İmgesi. H. Kuruoğlu (Ed.) Erkek Kimliğinin Değişe(Meye)N Hâlleri. İçinde (s.121-145).İstanbul: Nobel Yayınevi.

Özsoy, A. (2004). Türkiye'de 1960'lar Dönemi Aile Melodramlarında Kadın ve Erkek İmgesi. F. D. Küçükkurt ve A. Gürata (Ed.) Sinemada Anlatı ve Türler. İçinde (s. 277-300). Ankara: Vadi Yayınları.

Paechter, C. F. (2007). Being Boys, Being Girls: Learning Masculinities And Femininities. London: Open University Press.

Pease, B. (2014). Reconstructing Masculinity Or Ending Manhood? The Potential And Limitations Of Transforming Masculine Subjectivities For Gender Equality. À. Carabí ve J. M. Armengol (Ed.) Alternative Masculinities For A Changing World. İçinde (s.17-34). New York: Palgrave Macmillan.

Reeser, T. W. (2010). Masculinities in Theory an Introduction. Oxford: Wiley Blackwell Publishing. Roberts, S. (2014). Introduction: Masculinities in Crisis? Opening The Debate. S. Roberts (Ed.) Debating Modern Masculinities: Change, Continuity, Crisis?. İçinde (s.1-16). New York: Palgrave Macmillan. 
Robinson, V. ve Hockey, J. (2011). Masculinities in Transition. New York: Palgrave Macmillan.

Ryan, M. ve Kellner, D. (2010). Politik Kamera Çağdaş Hollywood Sinemasının İdeolojisi ve Politikası. İstanbul: Ayrıntı Yayınları.

Sancar, S. (2016). Erkeklik: Imkânsız iktidar Ailede, Piyasada ve Sokakta Erkekler. İstanbul: Metis Yayıncılık.

Saydam, B. (2013). Erkeklik Krizinin Gölgesinde Türkiye Sineması. Hayal Perdesi Dergisi,32, 56-65.

Segal, L. (1992). Ağır Çekim Değişen Erkeklikler Değişen Erkekler. (Çev: V. Ersoy). İstanbul: Ayrıntı Yayınları.

Segal, L. (1993). Changing Men: Masculinities in Context. Theory and Society,22(5), 625-641.

Selek, P. (2014). Sürüne Sürüne Erkek Olmak . İstanbul: Iletişim Yayınları.

Smelik, A. (2006). Feminist Sinema ve Film Teorisi -ve Ayna Çatladı. (Çev. D. Koç). İstanbul :Agora Kitaplığı.

Şoray, T. (2011). Sinema Öylesine Güçlü Bir Şey Ki, Canlandırdığınız Karakterlerle İnsanı ve Kendinizi Tanıyorsunuz. E. Aktaş (Der.) Sinema Söyleşileri-2010. İçinde (s.191-209). İstanbul: Boğaziçi Üniversitesi Yayınevi.

Ulusay, N. (2004). Günümüz Türk Sinemasında Erkek Filmlerinin Yükselişi ve Erkeklik Krizi. Toplum ve Bilim.101,144-161.

Ulusoy, N. (2015). Bana Derler Şoför Nebahat: Bir "Gelinlik Kız”ın Karşıt Giysici Olarak Portresi. Doğu Batı Düşünce Dergisi,72, Sinema Tutkusu-1,197-212.

Uluyağcı, C. (2001). Sinemada Erkek İmgesi: Farkı Sinemalarda Aynı Bakış. Kurgu Dergisi,18,29-39.

Vardan, U. (2009). Hat-Trick Yapmak İster Bu Deli Gönül. http://www.radikal.com.tr/yazarlar/ugurvardan/hat-trick-yapmak-ister-bu-deli-gonul-970053/. Erişim Tarihi:11.10.2018

Yavuz, Ş. (2014). İktidar Olma Sürecinde Erkeklerin Erkeklikle İmtihanı. Millî Folklor, 104, 110127.

Yücel, Ş. (2012). 80’lerden Günümüze Sinemada Kadın Temsilleri. M. Taşkaya ve E. U. İlbuğa (Ed.) Sinemada Kadın. İçinde (s.45-50). Antalya: Aksav Antalya Kültür Sanat Vakfı Yayınları.

Yüksel, E. (2013). Bir Savaş Anlatısı Olarak Nefes: Vatan Sağolsun ve Hegemonik Erkekliğin Krizi. Fe Dergi, 5(1),15-31. 